\title{
Vitamin D and cardiometabolic health: a review of the evidence
}

\author{
Siobhan Muldowney and Mairead Kiely* \\ Vitamin D Research Group, School of Food and Nutritional Sciences, University College Cork, Republic of Ireland
}

\section{Abstract}

The cardiometabolic syndrome (MetS) is a clustering of related metabolic abnormalities including abdominal adiposity, insulin resistance, hypertension, dyslipidaemia and increased inflammatory and thrombotic markers, which is linked to increased risk of type 2 diabetes, CVD and overall mortality. Several cross-sectional and prospective studies have shown an association between low vitamin D status, as indicated by concentrations of serum 25-hydroxyvitamin D (s25(OH)D), and increased prevalence of the MetS and individual CVD risk factors. These epidemiological observations are supported by mechanistic studies but experimental data are limited. The available data from intervention studies are largely confounded as most vitamin D supplementation trials were mainly carried out to explore the role of Ca in CVD and include $\mathrm{Ca}$ in the treatment arms. Inadequate consideration of seasonal effects on s25(OH)D concentrations is also a common design flaw in most studies. Further complications arise from shared risk factors such as adiposity and ageing, which predispose individuals to exhibit both a more pronounced risk profile and relatively lower s25(OH)D concentrations. In conclusion, while epidemiological associations are promising and a rationale for low vitamin D status as a potentially modifiable risk factor for CVD is supported by mechanistic data, suitable experimental data from appropriately designed trials are just beginning to emerge. As yet, this body of literature is too immature to draw firm conclusions on the role of vitamin D in CVD prevention. Carefully controlled vitamin D trials in well-described population groups using intervention doses that are titrated against target s25(OH)D concentrations could yield potentially valuable outcomes that may have a positive impact on CVD risk modification.

Key words: Vitamin D: CVD: Metabolic syndrome: Type 2 diabetes: Obesity: Hypertension: Inflammation: Insulin resistance

\section{Introduction}

CVD is a major cause of mortality and morbidity. In 2005, CVD accounted for $35.3 \%$ of all deaths in the $\mathrm{USA}^{(1)}$. Similarly, in Ireland, CVD resulted in $35 \%$ of all deaths in $2006^{(2)}$. Non-modifiable risk factors of CVD include increasing age, sex, family history and ethnicity ${ }^{(3)}$, whereas modifiable risk factors include abnormal blood lipids (low HDL-cholesterol, apoB/apoA1), smoking, diabetes, high blood pressure, abdominal obesity, lack of physical exercise, diet, psychosocial stress and over-consumption of alcohol $^{(4)}$.

The cardiometabolic syndrome (MetS), first described by Kylin $^{(5)}$, is defined as a clustering of metabolic abnormalities including obesity, high fasting blood glucose, insulin resistance, hypertension and dyslipidaemia, which are linked to increased risks of serious health complications such as type 2 diabetes, CVD, stroke and kidney failure. An estimated 47 million US residents have the MetS; the prevalence ranges from $6 \cdot 7 \%$ among young adults aged 20-29 years to $43.5 \%$ among older adults aged 60-69 years and $42 \%$ among those aged $\geq 70$ years $^{(6)}$. The prevalence of the MetS is $15 \%$ in non-diabetic European adults over 30 years ${ }^{(7)}$ and this is expected to rise with increasing prevalence of obesity. In a subsample of middle-aged Irish men and women ( $n$ 1018; aged 50-69 years), Villegas et $a l .{ }^{(8)}$ estimated the prevalence of the MetS to be $21 \%$ using the definition proposed by the $\mathrm{WHO}^{(9)}$ or $20.7 \%$ according to Third National Cholesterol Education Program Adult Treatment Panel (NCEP/ATP III) criteria $^{(10)}$.

Identification of the multiple genetic and environmental factors that predispose some overweight individuals to developing the various metabolic disorders that constitute the MetS would be a valuable step in helping to address the condition. In this context, nutrition, including vitamin D status, is potentially a modifiable risk factor. Numerous reports have linked low vitamin D status with an increased

Abbreviations: $1,25(\mathrm{OH})_{2} \mathrm{D}, 1,25$-dihydroxyvitamin $\mathrm{D} ; 25(\mathrm{OH}) \mathrm{D}, 25$-hydroxyvitamin $\mathrm{D}$; CRP, C-reactive protein; CYP27B1, 25-hydroxyvitamin $\mathrm{D}_{3}-1$ - $\alpha$ hydroxylase; DBP, diastolic blood pressure; HOMA-IR, homeostasis model assessment of insulin resistance; HR, hazard ratio; IGF, insulin-like growth factor; MetS, cardiometabolic syndrome; MMP, matrix metalloproteinase; NCEP/ATP III, Third National Cholesterol Education Program Adult Treatment Panel; NHANES, National Health and Nutrition Examination Survey; PAI-1, plasminogen activator inhibitor type 1; PTH, parathyroid hormone; RAS, renin-angiotensin system; RCT, randomised controlled trial; RR, relative risk; RXR, retinoic acid X receptor; s25(OH)D, serum 25-hydroxyvitamin D; SBP, systolic blood pressure; TIMP, tissue inhibitor of metalloproteinase; UVB, UV blue; VDR, vitamin D receptor.

*Corresponding author: Dr Mairead Kiely, fax +35321 4270244, email m.kiely@ucc.ie 
risk of the MetS and CVD risk ${ }^{(11,12)}$. Therefore, given both the increasing prevalence of the MetS among adults and evidence of widespread low vitamin D status, exploration of these relationships could be a valuable step towards addressing one (or both) problems.

\section{Scope of review and approach}

The present review will describe epidemiological associations between vitamin D and cardiometabolic health. It will outline the mechanisms proposed for the association and will evaluate the recent experimental evidence. Searches were made on PubMed and ISI Web of Knowledge ${ }^{\mathrm{sm}}$ up to May 2010 using search terms to capture generic and specific words relevant to the topic, including 'vitamin D', 'cholecalciferol', 'cardiovascular disease', 'metabolic syndrome', 'cardio-metabolic syndrome', 'blood pressure', 'hypertension', 'glucose', 'diabetes', 'insulin', 'insulin resistance', 'glucose metabolism', 'lipids', 'dyslipidemia', 'cholesterol', 'high-density lipoprotein', 'HDL', 'low-density lipoprotein', 'LDL', 'inflammation', 'C-reactive protein', 'CRP', 'interleukin-6', 'IL-6', 'tumour necrosis factor alpha', 'TNF- $\alpha$ ', 'plasminogen activator inhibitor type 1' (PAI-1), 'matrix metalloproteinases', 'adhesion molecules'(ICAM-1 and VCAM-1), and combinations of these. We also manually searched bibliography lists of some primary articles for additional studies. The search on randomised controlled trials (RCT) was carried out from January 1990 to May 2010, and excluded RCT that used calcitriol (1,25-dihydroxyvitamin $\left.\mathrm{D}\left(1,25(\mathrm{OH})_{2} \mathrm{D}\right)\right)$ or vitamin $\mathrm{D}$ analogues (for example, $1 \alpha$-calcidiol). RCT using cholecalciferol or ergocalciferol, alone or in combination with $\mathrm{Ca}$, were included; however, no RCT using ergocalciferol were identified in the time-frame specified, except for one which looked primarily at risk of falls. We restricted the search to articles in English.

\section{Vitamin D endocrine system}

The two most common forms of vitamin $\mathrm{D}$ are ergocalciferol (vitamin $\mathrm{D}_{2}$ ) and cholecalciferol (vitamin $\mathrm{D}_{3}$ ). Cholecalciferol is synthesised on skin exposure to UV blue (UVB) radiation. In the skin, 7-dehydrocholesterol is converted to precholecalciferol (pre-vitamin D), which is unstable. Through thermal isomerisation, pre-vitamin D is converted to cholecalciferol. Extra vitamin $\mathrm{D}_{3}$ can be obtained from the diet, although sources are limited and include oily fish, egg yolks and fortified foods. Ergocalciferol is produced by UV irradiation of the fungal steroid ergosterol and is used in some vitamin D supplements. Although the relative ability of vitamin $D_{2}$ to increase vitamin $D$ status (as indicated by serum concentrations of 25-hydroxyvitamin $\mathrm{D}(\mathrm{s} 25(\mathrm{OH}) \mathrm{D}))$ compared with vitamin $\mathrm{D}_{3}$ was previously disputed, recent data from Holick et al. ${ }^{(13)}$ showed that vitamin $D_{2}$ was as effective as vitamin $D_{3}$.

Both forms of vitamin D eventually enter the circulation and, bound to the vitamin $\mathrm{D}$ binding protein, are transported to the liver where the first of two hydroxylation steps occurs, producing the predominant circulating vitamin D metabolite, 25-hydroxyvitamin D (25(OH)D). Still bound to the vitamin D binding protein, $25(\mathrm{OH}) \mathrm{D}$ is transported around the body. The enzyme, 25-hydroxyvitamin $\mathrm{D}_{3}-1-\alpha$-hydroxylase (CYP27B1), which is a member of the $\mathrm{P}_{450}$ family, is responsible for the second hydroxylation step, which produces $1,25(\mathrm{OH})_{2} \mathrm{D}$, the active form of vitamin D. While CYP27B1 is located in many cells throughout the body, including smooth muscle cells, immune cells and pancreatic $\beta$-cells, the primary site of this hydroxylation step is in the mitochondria of the renal cortex, which appears to be tightly controlled by parathyroid hormone (PTH) for the maintenance of Ca homeostasis. However, non-renal CYP27B1 appears to operate outside this control $^{(14)}$. The most accurate method of determining an individual's vitamin $D$ status is to measure $25(\mathrm{OH}) \mathrm{D}$ concentrations in serum. Serum $25(\mathrm{OH}) \mathrm{D}$ circulates at about 1000 times the concentration of $1,25(\mathrm{OH})_{2} \mathrm{D}$ and has a longer half-life of approximately 2 weeks ${ }^{(15)}$.

The action of vitamin $\mathrm{D}$ is achieved through a vitamin $\mathrm{D}$ receptor (VDR)-mediated mechanism in which $1,25(\mathrm{OH})_{2} \mathrm{D}$ regulates transcription of a wide variety of genes in vitamin $\mathrm{D}$ target cells ${ }^{(16)}$. This mechanism involves forming a heterodimeric complex with a retinoic acid $\mathrm{X}$ receptor $\left(1,25(\mathrm{OH})_{2} \mathrm{D} / \mathrm{VDR} / \mathrm{RXR}\right)$; once this complex binds with a vitamin D-responsive element it can exert various actions. In addition, $1,25(\mathrm{OH})_{2} \mathrm{D}$ can act through intra-cellular signalling pathways activated via plasma membrane receptors. The VDR has been identified in most body cells, including the small intestine, colon, brain, skin, prostate, gonads, breast, lymphocytes, macrophages, smooth muscle and $\beta$-cells ${ }^{(15)}$, which has led to the hypothesis that vitamin $D$ is implicated in the pathogenesis of many disorders, including certain types of cancer, diabetes (type 1 and type 2), CVD and several immune and inflammatory-related diseases ${ }^{(15,17)}$.

\section{Links between vitamin D and CVD}

The story linking vitamin D and CVD has evolved substantially since the first studies, which date back to the 1960s. Data from animal studies suggested that hypevitaminosis D caused calcification and was involved in the pathogenesis of atherosclerosis ${ }^{(18-20)}$. In human subjects, Linden ${ }^{(21)}$ showed evidence indicating that supplementary vitamin $\mathrm{D}$ was hypercholesterolaemic and increased the risk of myocardial infarction, and few studies found contradictory results ${ }^{(22,23)}$. Recent research in the field has proceeded along conventional lines, where mechanistic and experimental data seek to explore, explain, prove or dismiss epidemiological associations between low vitamin D status and indicators of metabolic dysfunction, the MetS and CVD.

With the increasing prevalence of obesity and a greater emphasis on the continuum which represents metabolic 
dysfunction and insulin resistance, with downstream progression to type 2 diabetes and eventually CVD, the research focus has shifted from specific studies on dyslipidaemia or hypertension to investigations of the interlinked metabolic irregularities which constitute the MetS. Several mechanisms are implicated in a putative role for vitamin D in CVD risk modification. Vascular smooth muscle contains VDR and CYP27B1, the enzyme necessary for the hydroxylation of $25(\mathrm{OH}) \mathrm{D}$ to $1,25(\mathrm{OH})_{2} \mathrm{D}$, suggesting that vasculature is an important target tissue for vitamin $\mathrm{D}^{(24)}$. Actions including suppression of vascular calcification, inhibition of vascular smooth muscle proliferation, modulation of inflammatory cytokines and regulation of the renin-angiotensin system (RAS) have all been described ${ }^{(25)}$.

To help the reader to weave through the large body of data available on this topic, we have taken a similar approach for each section of the present review: with respect to CVD, type 2 diabetes and the MetS as primary adverse health outcomes, as well as for contributing clinical risk factors, such as obesity, hypertension, dyslipidaemia, insulin resistance and inflammation, we have summarised epidemiological associations between the prevalence of each outcome or risk factor and vitamin D status, and followed this with an appraisal of the experimental and mechanistic data available.

\section{CVD}

It is interesting to note that the rate of CVD-related death is elevated at higher latitudes. However, data directly relating vitamin D status to the risk of CVD are meagre ${ }^{(26)}$. Using data from the Health Professionals Follow-up Study, Giovannucci et al. ${ }^{(27)}$ showed that men ( $n$ 18225) with a $\mathrm{s} 25(\mathrm{OH}) \mathrm{D}<37.5 \mathrm{nmol} / 1$ were at increased risk for myocardial infarction (RR 2.09; $95 \%$ CI 1.24, 3.54) compared with those above $75 \mathrm{nmol} / \mathrm{l}$ after controlling for age, smoking status, BMI, family history, alcohol consumption, physical activity, history of diabetes mellitus and hypertension, ethnicity, marine $n-3$ intake, LDL- and HDL-cholesterol and TAG. Similarly, the Ludwigshafen Risk and Cardiovascular Health study reported an independent association of low s25(OH)D (median $19 \mathrm{nmol} / \mathrm{l}$ ) with all-cause (hazard ratio (HR) 2.08; $95 \%$ CI 1.60, 2.70) and cardiovascular mortality (HR 2.22; $95 \%$ CI $1.57,3.13$ ) compared with high s25(OH)D (median $70 \cdot 9 \mathrm{nmol} / \mathrm{l})^{(12)}$.

With respect to intervention studies, two large RCT have examined the effect of cholecalciferol (alone ${ }^{(28)}$ or in combination with $\mathrm{Ca}^{(29)}$ ) on CVD events. In the UK, Trivedi et al. ${ }^{(28)}$ showed no effect of $100000 \mathrm{IU}$ cholecalciferol every 4 months for 5 years (about $20 \mu \mathrm{g} / \mathrm{d}$ ) on mortality from CVD in 2686 elderly adults (although it was suggestive of a reduced risk; RR $0 \cdot 84 ; 95 \% \mathrm{CI} 0 \cdot 65,1 \cdot 10 ; P=0 \cdot 2$ ). It is important, however, to note that the primary outcome of this trial was fracture incidence, for which a protective effect of supplementation was noted. Hsia et al. ${ }^{(29)}$ evaluated the risk of coronary and cerebrovascular events in the Women's Health
Initiative trial of Ca plus vitamin D supplementation. This trial appears several times during the course of the present review. Briefly, 36282 postmenopausal women aged between 50 and 79 years were randomised to receive either $1000 \mathrm{mg}$ elemental Ca plus $10 \mu \mathrm{g}$ cholecalciferol per $\mathrm{d}$, or a matching placebo. After 7 years of follow-up, no effect on coronary or cerebrovascular risk was observed ${ }^{(29)}$. Similarly, a more recent analysis of the Women's Health Initiative reported no difference in total and cause-specific mortality (including CVD and CHD deaths) in those who received the $\mathrm{Ca}$ and vitamin $\mathrm{D}$ supplementation compared with placebo ${ }^{(30)}$. There are a number of points to note with respect to the conduct of this trial and implications of the study outcomes; vitamin D and Ca supplementation was permitted among participants in addition to the randomisation protocol. Moreover, compliance was low, with approximately $60 \%$ of participants adhering to an $80 \% \mathrm{com}-$ pliance rate. Lastly, habitual intakes of vitamin $\mathrm{D}$ and $\mathrm{Ca}$ were quite high (about $9.2 \mu \mathrm{g} / \mathrm{d}$ and about $1150 \mathrm{mg} / \mathrm{d}$, respectively). A third RCT, albeit with falls prevention as the primary outcome, looked at the effect of intervening with ergocalciferol $(25 \mu \mathrm{g} / \mathrm{d})$ plus $\mathrm{Ca}(1000 \mathrm{mg} / \mathrm{d})$ for 1 year in elderly women (aged 70-90 years) with a baseline $\mathrm{s} 25(\mathrm{OH}) \mathrm{D}<60 \mathrm{nmol} / \mathrm{l}^{(31)}$. While the intervention reduced the risk of falls there was no effect on the risk of IHD or stroke. A recent meta-analysis ${ }^{(32)}$ reviewing whether Ca supplementation increased the risk of myocardial infarction and other cardiovascular events in adults (aged $>40$ years) with, or at risk of osteoporosis, showed that $\mathrm{Ca}$ supplementation $(>500 \mathrm{mg} / \mathrm{d})$ increased the risk of myocardial infarction (HR 1.31; $95 \%$ CI 1.02, 1.67). These data imply that giving Ca with vitamin D in RCT may obscure any benefits of vitamin D on reducing cardiovascular events and strengthens the need for vitamin D-only RCT to examine CVD incidence and mortality as a primary outcome.

\section{Cardiometabolic syndrome}

Several sets of definitive criteria are available to describe the $\operatorname{MetS}^{(9,10,33-35)}$, which are used to guide therapeutic and clinical interventions as well as public health policy. The two most commonly used definitions are provided by the US National Cholesterol Education Program report $^{(10)}$ and the International Diabetes Federation ${ }^{(33)}$. The two definitions are similar and will identify many of the same individuals as having the MetS. However, the International Diabetes Federation regards an increased waist circumference as an essential criterion for diagnosis, while the NCEP/ATP III requires the presence of any three criteria as sufficient, plus, while the International Diabetes Federation uses ethnic-specific cut-offs for waist circumference, the NCEP/ATP III use only one set of cut-offs, regardless of ethnicity.

The importance of identifying subjects with the MetS is because they are at increased risk of developing CVD, type 2 diabetes, stroke and kidney failure and in addition, 
each component can be treated on an individual basis. Hu et $a{ }^{(7)}{ }^{(7)}$, using data from eleven prospective European cohort studies, reported HR for cardiovascular mortality in adults with the MetS (defined by WHO criteria) of $2 \cdot 26$ (95\% CI 1.61, 3.17) and 2.78 (95\% CI 1.57, 4.94) in men and women, respectively, after controlling for age, blood cholesterol concentration and smoking. Clustering these risk factors has advantages over the analysis of the single entities by themselves. A prospective study, with a 6.9-year follow-up of first-degree relatives of patients with type 2 diabetes ( $n$ 4483), showed the relative risk (RR) for having CHD was greater in patients with the MetS (RR 2.96) compared with obesity (RR 1.44), dyslipidaemia (RR 1.73), hypertension (RR 1.57), insulin resistance (RR 1.53) and microalbuminuria (RR 0.94) ${ }^{(36)}$.

Low vitamin D status has been associated with an increased risk of the MetS (Ford et al. (11); Forouhi et al. ${ }^{(37)}$; Hypponen et al. ${ }^{(38)}$; Reis et al. ${ }^{(39)}$; S Muldowney, A Lucey, G Paschos, et al., unpublished results; M Kiely, S Muldowney, TR Hill, et al., unpublished results). Using data from National Health and Nutrition Examination Survey (NHANES) III in almost 8500 adults (aged $\geq 20$ years), Ford et al. ${ }^{(11)}$ observed subjects in the lowest quintile of $\mathrm{s} 25(\mathrm{OH}) \mathrm{D}(\leq 48.4 \mathrm{nmol} / \mathrm{l})$ were twice as likely to have the MetS compared with those in the highest quintile ( $\geq 96.4 \mathrm{nmol} / 1)$. Forouhi et al. ${ }^{(37)}$, using data from the Medical Research Council Ely Prospective Study, showed that in non-diabetic adults aged $\geq 40$ years ( $n$ 524), baseline s25(OH)D was inversely associated with 10-year increased risk of the MetS. In a cross-sectional analysis of the 1958 British Birth Cohort, Hypponen et al. ${ }^{(38)}$ also showed in 6810 adults aged $44-46$ years that s25(OH)D concentration was inversely associated with the prevalence of the MetS. Both of these studies showed interactions between s25(OH)D and insulin-like growth factor (IGF)1 ; in the 1958 birth cohort, risk of the MetS was lowest among those with highest levels of both s25(OH)D and IGF-1 ${ }^{(38)}$ whereas in the Ely cohort ${ }^{(37)}, 25(\mathrm{OH}) \mathrm{D}$ increased with increasing IGF-1, which, in those with high IGF-1, was inversely related to IGF binding protein- 1 and $2 \mathrm{~h}$ glucose concentration. Further analysis of the mechanisms by which $25(\mathrm{OH}) \mathrm{D}$ and the IGF-1 and IGF binding proteins interact is warranted to discover their influence on insulin and glucose secretion and/or sensitivity. Another recent cross-sectional analysis of 1654 men and women reported a substantially lower OR for the MetS in the highest quintile of s25(OH)D (median $88.0 \mathrm{nmol} / \mathrm{l}$; OR 0.15) compared with the lowest quintile (median $26.8 \mathrm{nmol} / \mathrm{l}$; OR 0.46$)^{(39)}$. Recently, we have shown in young overweight adults that those with a s25(OH)D $<42.5 \mathrm{nmol} / 1$ were more likely to have the MetS (OR 3.46; 95\% CI 1.07, 11.18) compared with subjects with a s25(OH)D $>63 \mathrm{nmol} / 1$ (S Muldowney, A Lucey, G Paschos, et al., unpublished results). Similarly, we showed in a representative sample of 12 - and 15 year-old adolescents that the risk of having the MetS was increased (OR 3.47; $95 \%$ CI 0.93, 13.01) in adolescents with a s25(OH)D $<48.2 \mathrm{nmol} / 1$ compared with those who had a s25(OH)D $>74.7 \mathrm{nmol} / 1$ (M Kiely, S Muldowney, TR Hill, et al., unpublished results). However, not all studies have observed this association ${ }^{(40-42)}$. McGill et al. ${ }^{(41)}$ showed in 243 obese adults, $80 \%$ of whom were women (age 47.6 (SD 12) years), that while s25 $(\mathrm{OH}) \mathrm{D}$ concentration was inversely associated with waist circumference, $\mathrm{BMI}$ and $\mathrm{HbA}_{1 \mathrm{c}}$, there was no association with the MetS. Using data from the Rancho Bernardo Study ( $n$ 1070; aged 44-96 years), Reis et al. ${ }^{(42)}$ showed no association between s25(OH)D and MetS risk despite the strong positive association between PTH and MetS risk (OR 2.02; 95\% CI 0.96, 4.24). In this latter study mean s25(OH)D concentration was high (men, 108.9 nmol/1; women, $101.6 \mathrm{nmol} / \mathrm{l}$ ) which may hide an association, if apparent. A recent systematic review and meta-analysis, using data from eight cross-sectional studies, showed that the prevalence of the MetS was reduced by approximately $50 \%$ (OR 0.49; 95\% CI 0.38, 0.64) by having high s25(OH)D concentration ${ }^{(43)}$.

\section{Glucose and insulin metabolism and type 2 diabetes}

Impaired glucose-mediated insulin production and/or insulin resistance are key components of the MetS. Defects in pancreatic $\beta$-cell function, insulin sensitivity, and systemic inflammation are often present before glucose intolerance and/or type 2 diabetes develop ${ }^{(7,44)}$. There are several potential mechanisms by which vitamin $\mathrm{D}$ may influence glucose tolerance, and insulin release or sensitivity $^{(45,46)}$.

Firstly, pancreatic $\beta$-cells contain VDR and express $1 \alpha$-hydroxylase ${ }^{(47)}$. Zeitz et al. ${ }^{(48)}$ reported that circulating glucose concentration was higher and insulin concentration was lower in mice with non-functioning VDR compared with wild-type mice. Local production of $1,25(\mathrm{OH})_{2} \mathrm{D}$ enhances the synthesis and release of insulin by $\beta$-cells in response to glucose stimulation ${ }^{(49)}$. Secondly, calbindin, a vitamin D-dependent Ca-binding protein, has long been known to be present in the pancreas of various species, including humans ${ }^{(50,51)}$. Sooy et al. ${ }^{(52)}$ showed that calbindin is an important regulator of insulin production, by regulating $\mathrm{Ca}$ concentration in the $\beta$-cell. Thirdly, s25(OH)D concentration was related to insulin sensitivity in a group of healthy non-diabetic adults ${ }^{(53)}$, and a recent animal study demonstrated that while $1,25(\mathrm{OH})_{2} \mathrm{D}$ treatment had no effect on insulin receptor expression in non-diabetic rats, it normalised the number of insulin receptors and improved insulin response to glucose transport in adipocytes in streptozotocin-induced diabetic rats, most probably by direct transcriptional activation of the rat insulin receptor gene ${ }^{(54)}$.

Elevated PTH concentrations have been shown to be inversely associated with insulin sensitivity in healthy adults $^{(55)}$, possibly through its effects on intracellular free Ca concentration of the pancreatic $\beta$-cell, adipocytes or 
muscle cells ${ }^{(56)}$. In some instances, PTH and not vitamin D has been associated with glucose tolerance ${ }^{(57)}$; however, other studies have found no association ${ }^{(40,58)}$.

VDR gene polymorphisms may also have a role to play. Several polymorphisms in the VDR gene have been described, with Apa I, Bsm I, Taq I and Fok I being the most commonly investigated in relation to type 2 diabetes, glucose homeostasis and insulin release ${ }^{(59,60)}$. Numerous case-control studies have found no difference in the distribution of VDR polymorphisms between diabetic patients and control subjects ${ }^{(61-63)}$; however, an association with a specific aspect, such as glucose intolerance or insulin secretion has been observed frequently ${ }^{(64-69)}$. Hitman et al. ${ }^{(64)}$ showed a strong association between higher insulin secretion and $A p a$ I VDR polymorphism (homozygous for the $A$ allele) in healthy Bangladeshi adults living in London and at risk of type 2 diabetes, independent of vitamin D status. An extension to this study showed that VDR polymorphisms of Taq I in all subjects and Taq I and Fok I in subjects with s25(OH)D $<50 \mathrm{nmol} / 1$ were independent determinants of insulin secretion ${ }^{(65)}$. Using data from The Rancho Bernardo Study, Oh \& Barrett-Connor ${ }^{(66)}$ reported that fasting plasma glucose and prevalence of glucose intolerance were lower in non-diabetic individuals with the $A A$ genotype compared with those with the $a a$ genotype. This study also observed that subjects with the $b b$ genotype of the Bsm I VDR polymorphisms were more likely to be insulin resistant compared with $B B$ carriers, which contrasts with a more recent study where no association was observed between the Bsm I VDR polymorphism and insulin resistance ${ }^{(67)}$. These contrasting results should be further explored, including possible interactions with potential confounders such as IGF-1 and its binding proteins ${ }^{(37,38)}$, as well as $\mathrm{PTH}^{(55,57)}$.

Other potential mechanisms may include effects through inflammatory processes ${ }^{(70,71)}$. Systemic inflammation is upregulated in type 2 diabetic patients ${ }^{(7,72,73)}$. While systemic inflammation has mainly been implicated in insulin resistance, elevated cytokines may initiate $\beta$-cell apoptosis. Vitamin D, through its inhibitory effect on pro-inflammatory cytokines $^{(74)}$, may improve insulin sensitivity and encourage $\beta$-cell survival ${ }^{(45)}$. Interactions between vitamin $D$ and inflammatory processes are described in more detail below.

Clinical evidence - observational studies. A high dietary intake of vitamin $\mathrm{D}$ and/or $\mathrm{Ca}$, and dairy foods has been inversely associated with glucose and insulin concentration and incidence of type 2 diabetes ${ }^{(75-78)}$. Using data from the Women's Health Study, Liu et al. ${ }^{(76)}$ reported that a total vitamin $\mathrm{D}$ intake above about $13 \mu \mathrm{g} / \mathrm{d}$ was associated with a lower risk of incident type 2 diabetes compared with intakes below $4 \mu \mathrm{g} / \mathrm{d}(P=0 \cdot 02)$. Another prospective study, using data from the first Nurses' Health Study ( $n$ 83779), reported that women who consumed $\geq 20 \mu \mathrm{g} / \mathrm{d}$ of vitamin D had a $23 \%$ lower risk of developing type 2 diabetes compared with women who consumed $\leq 5 \mu \mathrm{g}$ vitamin $\mathrm{D} / \mathrm{d}$ after controlling for BMI, age, physical activity, alcohol and caffeine use, family history of diabetes, smoking, hypertension and state of residence ${ }^{(78)}$ (additional adjustment for other dietary factors removed significance). These effects reflected intakes from supplements; women who obtained $\geq 10$ $\mu \mathrm{g} / \mathrm{d}$ vitamin D from supplements had a $13 \%$ lower risk of type 2 diabetes than women who took $\leq 2.5 \mu \mathrm{g} / \mathrm{d}$, after adjusting for the same covariates plus dietary factors including $\mathrm{Ca}$. This prospective study showed the effects of Ca and vitamin D in combination, in that women with the highest vitamin $\mathrm{D}(\geq 20 \mu \mathrm{g} / \mathrm{d})$ and highest Ca intakes $(1200 \mathrm{mg} / \mathrm{d})$ had the lowest risk of diabetes (RR 0.67; $95 \%$ CI 0.49, 0.90).

Using data from NHANES III, Scragg et al. ${ }^{(79)}$ reported that $s 25(\mathrm{OH}) \mathrm{D}$ concentration was inversely related to the presence of type 2 diabetes and increased insulin resistance in US adults (aged $40-74$ years); the OR for diabetes was $0 \cdot 25(95 \% \mathrm{CI} 0 \cdot 11,0 \cdot 60)$ in non-Hispanic whites with s25(OH)D concentration $\geq 81 \mathrm{nmol} / 1$ compared with those $\leq 43.9 \mathrm{nmol} / \mathrm{l}$. A cross-sectional analysis of the Framingham Offspring Study in 808 non-diabetic subjects (mean age 59.6 (SD 0.3) years) found that plasma $25(\mathrm{OH}) \mathrm{D}$ concentration (mean $47.4(\mathrm{SD} 0 \cdot 6) \mathrm{nmol} / \mathrm{l}$ ) was inversely associated with fasting plasma glucose, insulin and the homeostasis model assessment of insulin resistance (HOMA-IR, an indicator of insulin resistance), but not $2 \mathrm{~h}$ post-oral glucose tolerance test glucose, after adjusting for age, sex, BMI, waist circumference and current smoking habits ${ }^{(80)}$. Subjects in the top third of vitamin D status (s25(OH)D $\geq 53.4 \mathrm{nmol} / \mathrm{l})$ had a $1.6 \%$ lower concentration of fasting plasma glucose ( $P$ for trend $=0.007$ ), a $9.8 \%$ lower concentration of fasting plasma insulin $(P$ for trend $=0.001)$ and a $12.7 \%$ lower HOMA-IR score $(P$ for trend $<0.001)$ compared with subjects in the bottom third of vitamin $\mathrm{D}$ status $(\mathrm{s} 25(\mathrm{OH}) \mathrm{D} \leq 38.6 \mathrm{nmol} / \mathrm{l})$. The HOMA-IR was only decreased in subjects with a plasma $25(\mathrm{OH}) \mathrm{D}$ concentration $>81 \mathrm{nmol} / \mathrm{l}$. In the Medical Research Council Ely Prospective Study, Forouhi et al. ${ }^{(37)}$ reported that s25(OH)D concentrations at baseline were inversely related with 10-year risk of hyperglycaemia, insulin resistance and the MetS. In a systematic review by Pittas et al. ${ }^{(45)}$ using data from four studies ${ }^{(57,58,79,81)}$, a summary OR for the association between s25(OH)D and type 2 diabetes of $0.54(95 \% \mathrm{CI} 0.23,1.27)$ was reported for the highest s25(OH)D concentration $(62.5-95 \mathrm{nmol} / \mathrm{l}) v$. the lowest $(25-57.5 \mathrm{nmol} / \mathrm{l})$.

There are three possible mechanisms for the development of the chronic complications of diabetes, glycation, polyol pathway and oxidative stress. Naturally, $\mathrm{Hb}$ is glycated to some extent $(5-10 \%)$, but this is increased (2- to 3-fold) in diabetics. Glycated $\mathrm{Hb}$ (most commonly $\mathrm{HbA}_{1 \mathrm{c}}$ ) levels are used as an index of recent blood glucose control. Inverse associations have been observed between s25(OH)D concentration and $\mathrm{HbA}_{1 \mathrm{c}}^{(38,81)}$, which may be more marked in obese subjects ${ }^{(82)}$. 


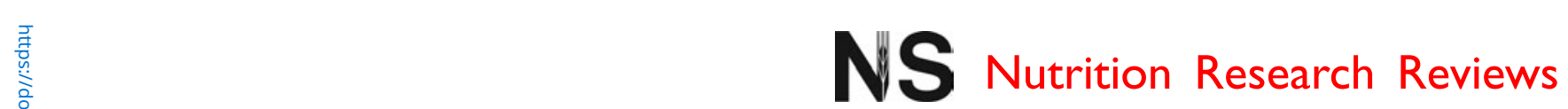

Table 1. The effect of cholecalciferol supplementation (as a single treatment) on cardiometabolic biomarkers

\begin{tabular}{|c|c|c|c|c|c|c|c|}
\hline Reference & Location & Subjects & Study design & $n$ & Dose & Duration & Effect \\
\hline $\begin{array}{l}\text { Muldowney et al. } \\
\quad \text { (unpublished results) }^{\star}\end{array}$ & Ireland & $\begin{array}{l}\text { Healthy, } M \text { and } F \text {, } \\
\text { aged } 20-40 \text { years } \\
\text { (YA) and } \geq 64 \text { years }(\mathrm{OA})\end{array}$ & RDBPCT & $\begin{array}{l}\text { Active: forty-nine YA, } \\
\text { forty-six OA } \\
\text { Active: fifty-seven YA, } \\
\text { fifty-one OA } \\
\text { Active: fifty-two YA, } \\
\text { fifty OA } \\
\text { Control: fifty-six YA, } \\
\text { fifty-three OA }\end{array}$ & $\begin{array}{l}10 \mu \mathrm{g} / \mathrm{d} \\
15 \mu \mathrm{g} / \mathrm{d}\end{array}$ & 6 months & $\begin{array}{l}\text { The seasonal increase in FG } \\
\text { was offset in YA who } \\
\text { received } 15 \mu \mathrm{g} / \mathrm{d} \\
\text { Fasting insulin, HOMA-IR in } \\
\text { YA or OA: no change. } \\
\text { FG in OA: no change } \\
\text { SBP, DBP in YA or OA: no change } \\
\text { Total, LDL-, or HDL-CHOL, } \\
\text { total CHOL:HDL, LDL:HDL, TAG in } \\
\text { YA or OA: no change, CRP in } \\
\text { YA or OA: no change }\end{array}$ \\
\hline $\begin{array}{l}\text { von Hurst et al. } \\
\qquad(2010)^{(85)}\end{array}$ & New Zealand & $\begin{array}{l}\text { South Asian, } F \text {, aged } \\
23-68 \text { years } \\
\text { s25(OH)D }<50 \mathrm{nmol} / \mathrm{l} \\
\mathrm{IR} \text {, and } / \text { or } \mathrm{TAG} / \mathrm{HDL} \geq 3.0\end{array}$ & RDBPCT & $\begin{array}{l}\text { Forty-two active } \\
\text { Thirty-nine control }\end{array}$ & $100 \mu \mathrm{g} / \mathrm{d}$ & 6 months & $\begin{array}{l}\text { FG, or } \beta \text {-cell function: no change } \\
\text { Insulin sensitivity: increased; IR, } \\
\text { fasting insulin: decreased } \\
\text { Total CHOL, or HDL-CHOL, } \\
\text { TAG, TAG:HDL: no change } \\
\text { CRP: no change }\end{array}$ \\
\hline $\begin{array}{l}\text { Jorde \& Figenschau } \\
\qquad(2009)^{(86)}\end{array}$ & Norway & $\begin{array}{l}\text { T2DM, } M \text { and } F \text { aged } \\
21-75 \text { years }\end{array}$ & $\begin{array}{l}\text { RDBPCT, stratified } \\
\text { by sex and } \\
\text { smoking status }\end{array}$ & $\begin{array}{l}\text { Sixteen active } \\
\text { Sixteen control }\end{array}$ & $142.9 \mu \mathrm{g} / \mathrm{d}$ & 6 months & $\begin{array}{l}\text { FG, insulin or } \mathrm{HbA}_{1 \mathrm{1c}} \text { : no change; } \\
\text { HOMA-IS or HOMA-IR: no } \\
\text { change; SBP, DBP: no change; } \\
\text { total CHOL, LDL-CHOL, } \\
\text { HDL-CHOL, TAG: no change }\end{array}$ \\
\hline $\begin{array}{l}\text { Nagpal et al. } \\
\qquad(2009)^{(83)}\end{array}$ & India & $\begin{array}{l}\text { Healthy obese, } \mathrm{M}, \\
\quad \text { aged } \geq 35 \text { years }\end{array}$ & RDBPCT & $\begin{array}{l}\text { Thirty-two active } \\
\text { Thirty-three control }\end{array}$ & $\begin{array}{l}3000 \mu \mathrm{g}, \\
\text { fortnightly }\end{array}$ & 6 weeks & $\begin{array}{l}\text { 3h OGIS: increased; insulin sensitivity, } \\
\text { } \text {-cell function: no change; SBP, } \\
\text { DBP: no change; total CHOL, } \\
\text { LDL-CHOL, HDL-CHOL, } \\
\text { VLDL-CHOL, TAG: no change }\end{array}$ \\
\hline $\begin{array}{l}\text { Zittermann et al. } \\
\qquad(2009)^{(111)}\end{array}$ & Germany & $\begin{array}{l}\text { Healthy, overweight, } \mathrm{M} \text { and } \mathrm{F} \text {, } \\
\text { aged } 18-70 \text { years }\end{array}$ & RDBPCT & $\begin{array}{l}\text { Eighty-two active } \\
\text { Eighty-three control }\end{array}$ & $83.3 \mu \mathrm{g} / \mathrm{d}$ & 12 months & $\begin{array}{l}\text { FG, proinsulin, } \mathrm{HbA}_{1 \mathrm{c}} \text { : no change; SBP, } \\
\text { DBP: no change; TAG: decreased; } \\
\text { HDL-CHOL: no change; } \\
\text { LDL-CHOL: increased; TNF- } \alpha \text { : } \\
\text { decreased; IL-6, CRP: no change }\end{array}$ \\
\hline \multirow[t]{2}{*}{$\begin{array}{l}\text { Andersen et al. } \\
\qquad(2009)^{(161)}\end{array}$} & \multirow[t]{2}{*}{ Denmark } & \multirow[t]{2}{*}{$\begin{array}{l}\text { Healthy Pakistani immigrants, } \\
\qquad \mathrm{M} \text { and } \mathrm{F} \text {, aged } 18-64 \text { years }\end{array}$} & \multirow[t]{2}{*}{ RDBPCT } & Fifty-six active & $10 \mu \mathrm{g} / \mathrm{d}$ & \multirow[t]{2}{*}{12 months } & $\begin{array}{l}\text { Total CHOL, LDL-CHOL, } \\
\text { HDL-CHOL, VLDL-CHOL, } \\
\text { LDL:HDL, TAG: no change }\end{array}$ \\
\hline & & & & $\begin{array}{l}\text { Sixty-one active } \\
\text { Fifty-six control }\end{array}$ & $20 \mu \mathrm{g} / \mathrm{d}$ & & \\
\hline $\begin{array}{l}\text { Tai et al. } \\
\qquad(2008)^{(210)}\end{array}$ & Australia & $\begin{array}{l}\text { Healthy, } M \text { and } F \text {, aged } 19-75 \\
\quad \text { years, s25(OH)D }<50 \mathrm{nmol} / \mathrm{I}\end{array}$ & Controlled trial & Thirty-three active & $2 \times 2500 \mu \mathrm{g}$ & 2 weeks & OGTT, insulin sensitivity: no change \\
\hline $\begin{array}{l}\text { Borissova et al. } \\
\qquad(2003)^{(84)}\end{array}$ & Bulgaria & T2DM, F, aged $43-63$ years & Controlled trial & $\begin{array}{l}\text { Ten active } \\
\text { Seventeen control }\end{array}$ & $33 \mu \mathrm{g} / \mathrm{d}$ & 1 month & $\begin{array}{l}\text { First-phase insulin secretion: improved; } \\
\text { second-phase insulin secretion: } \\
\text { no change; IR: no change }\end{array}$ \\
\hline \multirow[t]{2}{*}{$\begin{array}{l}\text { Van den Berghe et al. } \\
\qquad(2003)^{(190)}\end{array}$} & \multirow[t]{2}{*}{ Belgium } & $\begin{array}{l}\text { ICU patients, } M \text { and } F \\
\text { aged }>18 \text { years }\end{array}$ & $\mathrm{RCT}$ & Twelve active & $12.5 \mu \mathrm{g} / \mathrm{d}$ i.v. & \multirow[t]{2}{*}{$10 d$} & CRP, IL-6: decreased \\
\hline & & & & $\begin{array}{l}\text { Ten active } \\
\text { Twenty-two control }\end{array}$ & $5 \mu \mathrm{g} / \mathrm{d}$ i.v. & & TNF- $\alpha$, IL-1: no change \\
\hline
\end{tabular}




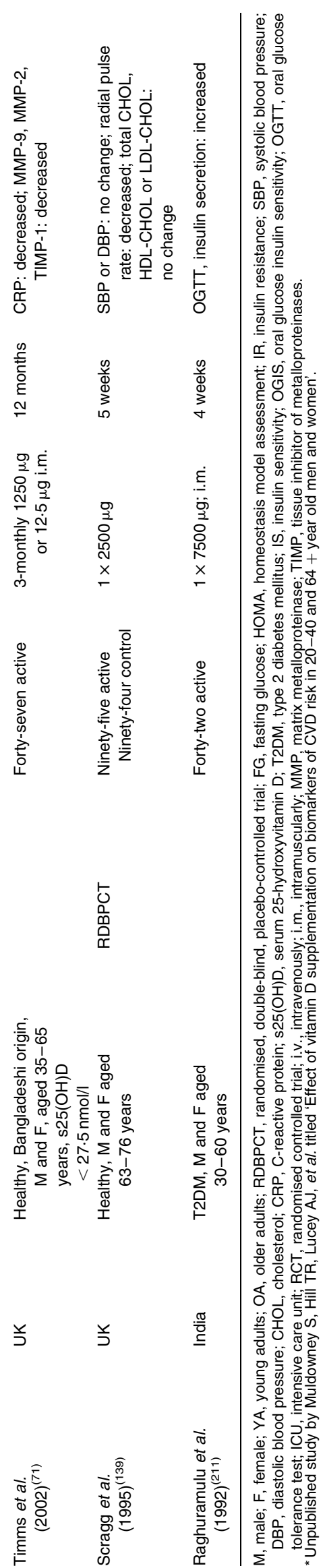

Intervention studies. Data from RCT are relatively rare and to the best of our knowledge have been limited to patients with type 2 diabetes or other underlying diseases (for example, uraemia), patients who are overweight, insulin resistant or vitamin D deficient. RCT with cholecalciferol (as a single treatment; see Table 1) improved insulin response to glucose in some ${ }^{(83-85)}$, but not all studies ${ }^{(86)}$. In India, Nagpal et al. ${ }^{(83)}$ showed that large doses of vitamin $\mathrm{D}_{3}$ (three $\times 3000 \mu \mathrm{g}$, fortnightly) improved postprandial insulin sensitivity after 6 weeks in centrally obese healthy men (aged $\geq 35$ years). Female type 2 diabetics, the vast majority of whom were vitamin D deficient, had improved first-phase insulin secretion and insulin resistance after supplementation with $33 \mu \mathrm{g}$ vitamin $\mathrm{D}_{3}$ per $\mathrm{d}$ for 1 month $^{(84)}$. In a more long-term RCT, insulin sensitivity, insulin resistance and fasting insulin concentration were improved after 6 months of supplementation with $100 \mu \mathrm{g}$ vitamin $\mathrm{D}_{3} / \mathrm{d}$ in South Asian women ( $n$ 81) who were insulin resistant (HOMA-IR $\geq 1.93$ ) and vitamin $\mathrm{D}$ deficient $(\mathrm{s} 25(\mathrm{OH}) \mathrm{D}<50 \mathrm{nmol} / \mathrm{l})$ at baseline ${ }^{(85)}$. In contrast, thirtysix type 2 diabetic patients, without vitamin D deficiency, who were randomised to receive $142.9 \mu \mathrm{g}$ vitamin $\mathrm{D}_{3} / \mathrm{d}$ or placebo for 6 months, showed no improvement in glycaemic control $^{(86)}$. Recently we completed an RCT in healthy adults, aged $20-40$ years and $\geq 64$ years, and showed that $15 \mu \mathrm{g}$ vitamin $\mathrm{D}_{3} / \mathrm{d}$ offset the seasonal increase in fasting glucose concentration in the younger adults (S Muldowney, TR Hill, AJ Lucey, et al., unpublished results).

Another reason why RCT are difficult to interpret is that they have been confounded by the combination of $\mathrm{Ca}$ with vitamin $\mathrm{D}$; therefore, in these studies it is not possible to be confident that the response observed is due to the vitamin $\mathrm{D}$ and/or $\mathrm{Ca}$. Additionally, if the findings of the recent meta-analysis ${ }^{(32)}$ with regard to cardiovascular events are correct, giving Ca with vitamin D may occlude the possible beneficial effects of vitamin D. Pittas et al. ${ }^{(87)}$ completed a post hoc analysis of 314 healthy adults, aged $\geq 65$ years, who had originally completed a double-blind, placebocontrolled trial designed to assess skeletal outcomes, where subjects received either $500 \mathrm{mg}$ calcium carbonate and $17.5 \mu \mathrm{g}$ vitamin $\mathrm{D}_{3}$ or a placebo daily for 3 years ${ }^{(88)}$. Positive effects of the supplementation compared with placebo on fasting plasma glucose and HOMA-IR were only apparent in subjects who had impaired fasting glucose at baseline (fasting plasma glucose $\geq 5.6 \mathrm{mmol} / \mathrm{l}$ ). In a large double-blind RCT ( $n$ 330) in Norway, no effect of $500 \mathrm{mg}$ Ca daily plus vitamin $\mathrm{D}_{3}$ (500 or $1000 \mu \mathrm{g} /$ week) was shown in overweight and obese $\left(>28-47 \mathrm{~kg} / \mathrm{m}^{2}\right)$ subjects on glucose metabolism after 1 year ${ }^{(89)}$. Similarly, using data from the Women's Health Initiative, de Boer et al. ${ }^{(90)}$ showed that the incidence of diabetes at age 7 years did not differ between those receiving $\mathrm{Ca}$ and vitamin $\mathrm{D}$ compared with those receiving the placebo and there was no difference in fasting plasma glucose, insulin or HOMA-IR. Thus, the association between s25(OH)D concentrations and altered glucose and insulin metabolism reported 
widely in cross-sectional and prospective studies requires confirmation by RCT using vitamin D only.

\section{Obesity}

The prevalence of obesity is increasing worldwide, most probably due to positive energy balance associated with increasing sedentary lifestyles. The WHO estimated that 1.6 billion adults were overweight and 400 million adults were obese worldwide in $2005^{(91)}$. In the USA, ageadjusted prevalence of obesity increased from $22.9 \%$ in NHANES III (1988-94) to $30.5 \%$ in $1999-2000^{(92)}$. Using data from the North/South Ireland Food Consumption Survey, McCarthy et al. ${ }^{(93)}$ reported that $39 \%$ of Irish adults were overweight and $17 \cdot 8 \%$ were obese, which compared with data from the Irish Nutrition Survey, $1990^{(94)}$, is nearly a two-fold increase in obesity in 10 years (1990-2000). In recent years, the evidence for excess body weight as a causative agent in the Mets has encouraged the use of an adiposity measure as an essential element of defining the MetS ${ }^{(33)}$

Numerous studies have observed that obesity is a negative predictor of vitamin D status (for a review, see PérezLópez $\left.{ }^{(95)}\right)$. For example, data from the sixth Tromso study, which was a longitudinal analysis ${ }^{(96)}$, showed an inverse association between s25(OH)D concentration and BMI in over 10000 adults. Hypponen \& Power ${ }^{(82)}$, using data from the 1958 British birth cohort ( $n$ 7189), observed that $80 \%$ of subjects (BMI $>30 \mathrm{~kg} / \mathrm{m}^{2}$ ) had a s25(OH)D $<75 \mathrm{nmol} / 1$, compared with $68 \%$ of the non-obese subjects. In another study on 243 ambulant adults (BMI $28-50 \mathrm{~kg} / \mathrm{m}^{2}$ ) enrolled in a weight-loss study, s25(OH)D concentration was inversely associated with weight $(P=0.0009)$, BMI $(P=0.005)$ and waist circumference $(P=0.03)$, but not body fat percentage ${ }^{(41)}$. This study also estimated a decrease of $0.74 \mathrm{nmol} / 1$ in $\mathrm{s} 25(\mathrm{OH}) \mathrm{D}$ per $1 \mathrm{~kg} / \mathrm{m}^{2}$ increase in BMI.

Compston et al. ${ }^{(97)}$ suggested that the inverse association between s25(OH)D and adiposity could be explained by the observation that obese individuals spend less time outdoors and are therefore exposed to less UVB radiation. However, a recent cross-sectional analysis of 385 healthy adults, aged $\geq 65$ years, showed that sun exposure did not explain the inverse association between s25(OH)D levels and adiposity ${ }^{(98)}$. Bell et al ${ }^{(99)}$ proposed that the vitamin D endocrine system is altered in obese subjects, with increased production of $1,25(\mathrm{OH})_{2} \mathrm{D}$ exerting negative feedback control on the hepatic synthesis of $25(\mathrm{OH}) \mathrm{D}$. In addition, animal studies have shown that $1,25(\mathrm{OH})_{2} \mathrm{D}$ increases lipogenesis and decreases lipolysis ${ }^{(100,101)}$, and, therefore, may contribute to obesity; however, $1,25(\mathrm{OH})_{2} \mathrm{D}$ concentration is not consistently higher in obese subjects ${ }^{(102,103)}$. Furthermore, $1,25(\mathrm{OH})_{2} \mathrm{D}$ is not consistently related to $25(\mathrm{OH}) \mathrm{D}$ status. The efficiency of epidermal vitamin D production does not appear to be impaired in obesity, but adipose tissue appears to sequester cholecalciferol and $25(\mathrm{OH}) \mathrm{D}$, making it unavailable to the circulation; thus obese individuals frequently have low s25(OH)D concentrations ${ }^{(104)}$. Several years ago, Arunabh et al. ${ }^{(105)}$ concluded that body fatness was inversely related to s25(OH)D levels in healthy women, but more recently, Freedman et al. ${ }^{(106)}$ confirmed a strong inverse association between $25(\mathrm{OH}) \mathrm{D}$ and visceral adiposity in African-Americans with diabetes. This latest finding has important implications for study design; if visceral fat is a potentially more powerful determinant of s25(OH)D levels in overweight individuals as well as a prognostic indicator of metabolic dysfunction, it may be more appropriate to measure visceral fat rather than overall body fatness.

Intervention studies. There is a plausible explanation to why vitamin $D$ may have a role in weight management; however, the evidence is limited, as most RCT use vitamin D in combination with $\mathrm{Ca}$. In Norway, 334 overweight/obese subjects were randomised to receive $500 \mathrm{mg}$ Ca daily plus vitamin $\mathrm{D}_{3}(500$ or $1000 \mu \mathrm{g} /$ week $)$ or placebo for 1 year ${ }^{(107)}$. However, there was no change in weight throughout the intervention. Using data from the Women's Health Initiative, Caan et $a l .{ }^{(108)}$ observed that postmenopausal women randomised to receive $\mathrm{Ca}$ and vitamin $\mathrm{D}_{3}$ had smaller average annual weight gain compared with the women taking the placebo; moreover, the favourable effect was strongest among women who had, at baseline, a Ca intake $<1200 \mathrm{mg} / \mathrm{d}$. Another RCT showed healthy, overweight and obese women ( $n$ 63), partaking in a 15-week energy restriction $(-700 \mathrm{kcal} / \mathrm{d} ; 2930 \mathrm{~kJ} / \mathrm{d})$ intervention, who were randomised to receive a daily supplement of $10 \mu \mathrm{g}$ vitamin $\mathrm{D}_{3}$ and $1200 \mathrm{mg} \mathrm{Ca}$, improved their blood lipid profile compared with women randomised to receive a placebo ${ }^{(109)}$; however, no difference in weight loss was observed between treatment groups. A reanalysis of this study, limited to women with a very low Ca intake (baseline $\mathrm{Ca}<600 \mathrm{mg} / \mathrm{d}$ ), showed that women receiving the combined vitamin D and Ca supplement had greater weight loss compared with those receiving the placebo ${ }^{(110)}$. A more recent study investigated the effects of vitamin D supplementation $(83 \mu \mathrm{g} / \mathrm{d})$ for 1 year on weight loss and cardiovascular risk factors in overweight subjects who were participating in a weight-loss programme ${ }^{(111)}$. Weight loss was similar in both treatment groups; however, combined vitamin D supplementation with weight loss resulted in a more pronounced improvement in several CVD risk markers than did weight loss alone. This RCT will be described later in the review. On the basis of this evidence, it is impossible to say whether vitamin $D$ has any direct effect on the maintenance of a healthy body weight.

\section{Elevated blood pressure}

Elevated blood pressure is a common and independent risk factor for CVD, including stroke, heart failure and CHD. The seventh report of the Joint National Committee on prevention, detection, evaluation, and treatment of high blood pressure provides the most recent US classification of blood pressure levels ${ }^{(112)}$. Using data from NHANES 
(1999-2000), Wang \& Wang ${ }^{(113)}$ reported that $27 \%$ of US adults ( $n$ 4805; aged $\geq 18$ years) had hypertension. The 2007 Survey of Lifestyle, Attitudes and Nutrition (SLÁN) showed in 1207 Irish adults (aged $\geq 45$ years) that the prevalence of hypertension was $60 \%{ }^{(114)}$. Hypertension can be treated with antihypertensive medication and improved by changing modifiable risk factors such as body weight, smoking, physical activity and diet. Dietary approaches to reduce blood pressure have focused on the role of $\mathrm{Na}$, fruit and vegetables and $\mathrm{Ca}$. Growing evidence indicates that vitamin D may have an association with blood pressure, although the data are not consistent ${ }^{(115)}$.

The role of $1,25(\mathrm{OH})_{2} \mathrm{D}$ in the RAS and its association with PTH are potential mechanisms by which vitamin D and blood pressure are linked. The RAS, also known as the renin-angiotensin-aldosterone system, helps regulate blood pressure, electrolyte levels, and volume homeostasis, and excessive RAS stimulation is associated with hypertension. Renin, a protease, primarily synthesised in the juxtaglomerular cell of the kidney, catalyses the conversion of angiotensinogen to angiotensin I, which is further cleaved to angiotensin II by angiotensin-converting enzyme in the capillaries of the lungs. Elevated angiotensin II raises blood pressure in one of two ways: (1) angiotensin II is a potent vasoconstrictor $^{(116)}$ and elevates blood pressure by increasing vascular resistance; (2) angiotensin II stimulates aldosterone secretion, which in turn, increases Na reabsorption in the kidney and therefore blood pressure is raised.

Circulating $1,25(\mathrm{OH})_{2} \mathrm{D}$ has been shown to play a role in the regulation of the RAS; for example, $1,25(\mathrm{OH})_{2} \mathrm{D}$ was negatively correlated $(r-0.65 ; P<0.001)$ with plasma renin activity ${ }^{(117)}$. In this study, $1,25(\mathrm{OH})_{2} \mathrm{D}$ was elevated in hypertensive subjects with low renin activity but not normotensive or hypertensive subjects with high renin activity. Renin expression and angiotensin II production are elevated in VDR knock-out mice ${ }^{(118)}$. However, the expression of angiotensinogen did not differ between VDR knock-out and wild-type mice and this indicates that the elevated production of angiotensin II is primarily due to the increase in renin activity. The observed hypertension, cardiac hypertrophy and increased water intake were corrected by treatment with an angiotensin-converting enzyme inhibitor (captopril) or an angiotensin II $\mathrm{AT}_{1}$ receptor antagonist (losartan), confirming that it was the RAS responsible for the observed abnormalities. In addition, that study showed that inhibition of $1,25(\mathrm{OH})_{2} \mathrm{D}$ led to up-regulation of renin and, furthermore, treatment with $1,25(\mathrm{OH})_{2} \mathrm{D}$ suppressed renin expression in wildtype mice. A continuation of this study, using As $4 \cdot 1$ cells, which are the best available in vitro model for a juxtaglomerular cell, showed that $1,25(\mathrm{OH})_{2} \mathrm{D}$ directly suppresses renin gene transcription, through a VDR-mediated mechanism. These results were supported by a second animal study ${ }^{(119)}$, where VDR knock-out mice developed excessive concentrations of renin in their blood, which led to high blood pressure. The molecular effects are still unknown but appear to be independent of both $\mathrm{Ca}$ and PTH concentration ${ }^{(119-121)}$. Instead, cyclic AMP, which is a major intracellular signal that stimulates renin expression, has been implicated. Yuan et al. ${ }^{(122)}$ showed that liganded VDR suppresses renin expression by binding to the transcription factor cyclic AMP-response element-binding protein. This inhibits renin transcription, as cyclic AMPresponse element-binding protein is no longer available for binding to the cyclic AMP response elements in the promoter region of the renin gene.

Besides its role in Ca homeostasis, PTH has a pro-sclerotic effect on vascular smooth muscle cells ${ }^{(123)}$ which may contribute to vessel-wall thickening and subsequent rises in blood pressure. Elevated circulating levels of $1,25(\mathrm{OH})_{2} \mathrm{D}$, as a result of increased PTH, stimulates $\mathrm{Ca}$ influx in a variety of cells, including the vascular smooth muscle cells, which results in contraction and increased vascular resistance, i.e. elevated blood pressure ${ }^{(124)}$.

Clinical evidence - observational studies. The first indication that vitamin $\mathrm{D}$ was related to blood pressure in humans was from observations that residents at higher latitudes, who experience decreased UVB exposure as a result, had higher systolic and diastolic blood pressure (SBP and DBP) ${ }^{(125)}$. In fact, UVB light was shown, in addition to increasing s25(OH)D concentration, to lower blood pressure in adults (aged 26-66 years) with essential hypertension $^{(126)}$.

Cross-sectional and prospective studies examining the relationship between vitamin $\mathrm{D}$ intake and blood pressure have reported conflicting results ${ }^{(127,128)}$; however, the evidence appears to be strongest for SBP. Sowers et al. ${ }^{(127)}$ examined eighty-six normotensive young women (aged 20-35 years) and 222 older normotensive women (aged 55-80 years) to investigate if $\mathrm{Ca}$ and vitamin $\mathrm{D}$ intakes affected bone density or blood pressure. In the young women, vitamin D intake above $10 \mu \mathrm{g} / \mathrm{d}$ was predictive of a lower SBP $(-6 \mathrm{mmHg})$ but no association was apparent with DBP. In the older women, having an intake of both vitamin D and Ca above $10 \mu \mathrm{g}$ and $800 \mathrm{mg} / \mathrm{d}$, respectively, was predictive of lower SBP. In a larger, more recent study of over 15000 generally healthy Norwegians (aged 25-69 years) who took part in the fourth Tromso study, no association between vitamin $\mathrm{D}$ intake and blood pressure was observed after multivariate adjustment ${ }^{(128)}$; however, very few subjects had a vitamin D intake $>10 \mu \mathrm{g} / \mathrm{d}$. Results from three large prospective studies, Nurses' Health Study I ( $n$ 77 436), Nurses' Health Study II ( $n$ 93, 803) and the Health Professionals Follow-up Study ( $n 38$ 074), found no evidence that a higher intake of vitamin $\mathrm{D}$ reduced (or increased) the risk of incident hypertension after multiple adjustments and approaches to the analysis ${ }^{(129)}$. Diagnosis of hypertension in this study was self-reported, and although self-reported hypertension in a health professionals' study is reasonably reliable, it does cast doubt over the study outcomes. Data from the Women's Health Study found that intakes of low-fat dairy products, Ca, and vitamin D were 
each inversely associated with risk of hypertension in middle-aged and older women ${ }^{(130)}$.

The association between s25(OH)D concentration and blood pressure is also inconsistent. Pasco et al. ${ }^{(131)}$ showed in a sample of Australian women ( $n$ 861; aged 2092 years) that the odds for having a high blood pressure was reduced in those with a $\mathrm{s} 25(\mathrm{OH}) \mathrm{D}$ in the top or middle third compared with those in the lowest third (median $40 \mathrm{nmol} / \mathrm{l}$ ), after accounting for weight and other potential confounders. Additionally, we recently reported that adolescents with a s25(OH)D $<60 \cdot 1 \mathrm{nmol} / 1$ were more likely (OR 1.94; $95 \%$ CI 1.18, 3.20) to have an elevated SBP $(>135 \mathrm{mmHg})$ compared with those who had a s25(OH)D $>60 \cdot 1 \mathrm{nmol} / 1$ (M Kiely, s Muldowney, TR Hill, et al., unpublished results). In contrast, Snijder et al. ${ }^{(132)}$ using data from the Longitudinal Aging Study Amsterdam observed no association between $25(\mathrm{OH}) \mathrm{D}$ concentration and blood pressure in 1205 elderly subjects; however, 80\% of these subjects had hypertension. Similarly, using data from the fourth and sixth Tromso Study, Jorde et al. ${ }^{(133)}$ showed that after adjustment for confounding, s25(OH)D did not predict future hypertension risk or increase in blood pressure. Three articles using data from NHANES III have reported on the association between vitamin $D$ and blood pressure/hypertension ${ }^{(134-136)}$. Scragg et al. ${ }^{(134)}$ showed that after multivariate adjustment for sex, age, ethnicity and physical activity, mean SBP and DBP were lower in the highest quintile of vitamin D status $(\mathrm{s} 25(\mathrm{OH}) \mathrm{D}>85.7$ $\mathrm{nmol} / \mathrm{l})$ than in the lowest quintile $(\mathrm{s} 25(\mathrm{OH}) \mathrm{D}<40.4$ $\mathrm{nmol} / \mathrm{l})$. Judd et al. $^{(135)}$ observed an inverse association between $25(\mathrm{OH}) \mathrm{D}$ and SBP in white, but not black, men and women; however, adjustment for age removed the association. In addition, this study showed that in white, but not black, subjects a s25(OH)D $>80 \mathrm{nmol} / 1$ reduced the age-related increase in SBP by $20 \%$ compared with white subjects with s25(OH)D $<50 \mathrm{nmol} / 1$, taking $\mathrm{BMI}$, sex, physical activity and smoking status into consideration. Further analysis of NHANES III indicates that having a s25 $(\mathrm{OH}) \mathrm{D}$ concentration $<52.5 \mathrm{nmol} / 1$ is associated with an increased risk of hypertension (OR 1.30; 95\% CI 1.13, 1.49) compared with having a $25(\mathrm{OH}) \mathrm{D} \geq 92.5 \mathrm{nmol} / \mathrm{l}^{(136)}$. The confounding effects of age and ethnicity in crosssectional studies could overpower any putative associations between 25(OH)D levels and blood pressure.

The question of whether low vitamin D status is a risk factor for the development of hypertension has been addressed by prospective studies. Using data from the Health Professionals Follow-up Study ( $n$ 613) and the Nurses' Health Study I ( $n$ 1198), Forman et al. ${ }^{(137)}$ showed that plasma $25(\mathrm{OH}) \mathrm{D}$ concentration was inversely associated with risk of incident hypertension in men and women, after 8 years of follow-up accounting for age, BMI, physical activity, race, menopausal status (for women) and other potential confounders. In analysis of the pooled data (Health Professionals Follow-up Study and Nurses' Health Study I), after 4 years of follow-up, individuals whose $25(\mathrm{OH}) \mathrm{D}$ levels were $<37 \cdot 5 \mathrm{nmol} / 1 \mathrm{com}-$ pared with those whose levels were $\geq 75 \mathrm{nmol} / 1$ had an RR for incident hypertension of 3.18 (95\% CI 1·39, 7·29). Using data from the Nurses' Health Study II, Forman et al. ${ }^{(138)}$ observed that women who were vitamin D deficient $(25(\mathrm{OH}) \mathrm{D}<75 \mathrm{nmol} / \mathrm{l})$ had a $47 \%$ increased risk (OR $1 \cdot 47$; $95 \%$ CI 1.10, 1.97) of incident hypertension after adjustment compared with those who had $25(\mathrm{OH}) \mathrm{D}>75 \mathrm{nmol} / \mathrm{l}$. This study estimated that vitamin D deficiency may account for $23.7 \%$ of all new cases of hypertension developing among young women every year. Collectively, these data indicate that the apparent inverse association between vitamin D status and blood pressure and hypertension is of a sufficient magnitude to have a potentially important impact on cardiovascular mortality ${ }^{(139)}$.

Intervention trials. To date, only one RCT using cholecalciferol only has been completed with blood pressure as the primary outcome (see Table 1 ). Scragg et al. ${ }^{(139)}$ randomised elderly ( $n$ 189; aged $63-76$ years) subjects to receive a single supra-physiological dose of vitamin $D_{3}$ $(2.5 \mathrm{mg})$ or a placebo during the winter; however, it had no effect on SBP or DBP. Unexpectedly, this study did report a decrease in radial pulse rate in subjects receiving the vitamin $\mathrm{D}$, which is a crude measure of cardiac function. The lack of a treatment effect on SBP or DBP in this study may be due to the short follow-up time ( 5 weeks) but is more probably due to the effect of age itself on blood pressure in subjects who have had hypertension for some time. The vascular damage resulting from longterm hypertension makes older subjects with established hypertension unsuitable candidates for studies of vitamin $\mathrm{D}$ supplementation for blood pressure reduction. Some RCT looking at CVD risk factors, or trials more specific to insulin or glucose metabolism, have also reported blood pressure data (see Table 1). We recently used data from a RCT with cholecalciferol to explore its effects on biomarkers of CVD (S Muldowney, TR Hill, AJ Lucey, et al., unpublished results); however, no effect on blood pressure was apparent (in young or older healthy adults). All other vitamin D RCT that reported blood pressure data were in combination with Ca or used UVB therapy ${ }^{(89,126,140-142)}$

In 1990, Orwoll \& Oviatt ${ }^{(140)}$ reported no effect of Ca $(1000 \mathrm{mg} / \mathrm{d})$ and cholecalciferol $(25 \mu \mathrm{g} / \mathrm{d})$ supplementation for 3 years on blood pressure in thirty-five men (aged 30-92 years) compared with thirty age-matched controls, but given the large age range, this study had insufficient power to detect a difference. Similarly, the Women's Health Initiative found no effect of $\mathrm{Ca}$ and cholecalciferol on blood pressure in postmenopausal women ${ }^{(141)}$. More recently, Jorde et $a l .^{(89)}$ showed that overweight and obese subjects who were randomised to receive $500 \mathrm{mg}$ Ca daily plus cholecalciferol (500 or $1000 \mu \mathrm{g} /$ week) for 1 year had a slightly higher increase in SBP compared with those who received the $\mathrm{Ca}$ plus a placebo $(2 \cdot 3 \mathrm{v}$. $-0.1 \mathrm{mmHg}$; however, this study was powered to examine an effect on weight loss not blood pressure. On 
the other hand, Pfeifer et al. ${ }^{(142)}$ randomised women, aged $\geq 70$ years, who were vitamin $\mathrm{D}$ insufficient $(\mathrm{s} 25(\mathrm{OH}) \mathrm{D}<50 \mathrm{nmol} / \mathrm{l})$ to receive daily either $1200 \mathrm{mg}$ Ca or $1200 \mathrm{mg}$ Ca plus $20 \mu \mathrm{g}$ cholecalciferol for 8 weeks. SBP fell by $13.1 \mathrm{mmHg}$ in women receiving the vitamin $\mathrm{D}$ plus $\mathrm{Ca}$, whereas in women receiving $\mathrm{Ca}$ alone, SBP reduced by $5 \cdot 1 \mathrm{mmHg}$. No difference in DBP was observed between the two treatment groups.

Mechanistic evidence is strong for an inverse association between vitamin D and blood pressure; however, the data available to date have added little support for a positive effect of vitamin D on blood pressure. A useful approach may be to select slightly younger adults without longstanding hypertension who have low vitamin D status for participation in RCT.

\section{Dyslipidaemia}

Cholesterol is an essential substance, synthesised in the body and obtained from the diet, and is necessary for maintaining cell membrane integrity and for the manufacture of hormones ${ }^{(143)}$. Cholesterol and TAG are transported in the circulation on lipoproteins synthesised in the liver. LDL carries $60-80 \%$ of the body's cholesterol, while HDL is involved in reverse cholesterol transport. Apoproteins facilitate cholesterol transport by providing recognition sites for cell-surface receptors and acting as cofactors for enzymes involved in the metabolism of lipoproteins. ApoA1 is the major apoprotein on HDL and is anti-atherogenic under most conditions. ApoB is associated with chylomicrons, VLDL (and their remnants) and LDL. All forms of apoB are potentially atherogenic if their metabolism is not regulated properly ${ }^{(143)}$. Lipoprotein(a), a lipoprotein subclass, is found in variable concentrations and its levels are highly heritable. Lipoprotein(a) is a potential risk factor for CVD as it interferes with plasminogen and stimulates the production of PAI-1, thus reducing fibrinolysis and promoting clot formation ${ }^{(144)}$.

Dyslipidaemia, an elevation in total cholesterol, or LDLcholesterol, TAG or a reduction in HDL-cholesterol concentration in the circulation, is a potent risk factor for CVD ${ }^{(145)}$. Atherosclerosis, the presence of extensive plaque (lipids, cholesterol, $\mathrm{Ca}$ and other substances) in the arteries, causes nearly $75 \%$ of all deaths from CVD in the USA. Low HDL-cholesterol and high TAG concentrations are independent predictors of $\mathrm{CVD}^{(146)}$. Elevated plasma lipoprotein(a) is an independent risk factor for the development of CHD in men, comparable in magnitude to a total cholesterol concentration $\geq 6.2 \mathrm{mmol} / 1$ or $\quad$ HDL-cholesterol $<0.9$ $\mathrm{mmol} / \mathrm{l}^{(147)}$. Using data from the National Heart, Lung, Blood Institute Family Heart Study, concentrations of lipoprotein(a) $>50 \mathrm{mg} / \mathrm{dl} \quad(500 \mathrm{mg} / \mathrm{l})$ were shown to increase the risk of early onset of coronary artery disease, especially if combined with other unfavourable lipid levels or non-lipid risk factors, such as hypertension, diabetes or smoking ${ }^{(148)}$. Vitamin D status has been associated with dyslipidaemia in some instances but the literature is conflicting and the evidence basis is still being gathered.

Potential mechanisms linking vitamin D and lipids have not been studied in great detail and the focus has been on the effect of $\mathrm{Ca}$, which implicates vitamin $\mathrm{D}$ indirectly through its role in maintaining $\mathrm{Ca}$ homeostasis. Increased Ca absorption reduces fatty acid absorption and increases faecal fatty acid content, most probably resulting from the formation of insoluble Ca-fatty soaps ${ }^{(149-151)}$. The decreased absorption of fat, especially saturated fat, reduces serum total cholesterol and LDL-cholesterol. Furthermore, $\mathrm{Ca}$ increases the conversion of cholesterol to bile acids for excretion ${ }^{(152)}$ and increased $\mathrm{Ca}$ absorption can decrease hepatic TAG formation ${ }^{(153)}$. An alternative mechanism may be a consequence of the suppressive effect of $1,25(\mathrm{OH})_{2} \mathrm{D}$ on PTH concentration. Raised PTH has been shown to be accompanied by a decrease in plasma post-heparin lipolytic activity ${ }^{(154)}$; thus the maintenance of appropriate PTH levels with optimal vitamin D status may decrease TAG concentration by increasing peripheral TAG removal.

Clinical evidence - observational studies. Vitamin D status has been inversely related to dyslipidaemia in some instances, but the literature is conflicting. Lipid levels vary seasonally and total cholesterol, LDL-cholesterol and TAG concentrations are higher during the winter ${ }^{(155)}$. Many ${ }^{(80,136,156)}$, but not all ${ }^{(53,157,158)}$, studies have shown inverse relationships between $25(\mathrm{OH}) \mathrm{D}$ and TAG concentrations. Martins et al. ${ }^{(136)}$ showed that in US adults, TAG was lower in those in the top quartile of $25(\mathrm{OH}) \mathrm{D}$ $(\geq 92.5 \mathrm{nmol} / \mathrm{l})$ than in those in the bottom quartile $(<52.5 \mathrm{nmol} / 1)$; however, there was no association between s25(OH)D and total cholesterol. In a smaller sample of 126 glucose-tolerant healthy adults, Chiu et $\mathrm{al}^{\left({ }^{53)}\right.}$ observed an inverse association between 25(OH)D and total cholesterol, and LDL-cholesterol (adjusting for sex, age, ethnicity, season, SBP and DBP, BMI, and waist-to-hip ratio); however, no association was apparent between 25(OH)D and HDL-cholesterol or TAG in this study. The sometimes reported association between s25(OH)D and HDL-cholesterol ${ }^{(80,157,158)}$ is not apparent in all studies ${ }^{(53)}$, but an association between 25(OH)D and apoA1 has been observed ${ }^{(157-159)}$.

The total cholesterol:HDL and LDL:HDL ratios are important predictors of increased risk of CVD. Using data from the Framingham Offspring Study ( $n$ 1739), Wang et $a l .^{(160)}$ observed that the total cholesterol:HDL ratio was higher in those with s25(OH)D below $37.5 \mathrm{nmol} / \mathrm{l}$. Although we saw no association between vitamin D status and lipid profiles in young European adults (S Muldowney, A Lucey, G Paschos, et al., unpublished results), we did observe associations in a representative sample of 12- and 15-year-old adolescents (M Kiely, S Muldowney, TR Hill, et al., unpublished results); those with a s25(OH)D below about $50 \mathrm{nmol} / 1$ were more likely to have elevated total cholesterol (OR 3.09; 95\% CI 1.33, 
7.21) and LDL-cholesterol (OR 2.09; 95\% CI 0.95, 4.59) compared with adolescents who had a s25(OH)D $>75$ nmol/1. These associations were stronger in boys than girls.

Intervention trials. There is a dearth of RCT on the effects of cholecalciferol on lipids (see Table 1). Zittermann et al. ${ }^{(111)}$ showed that treatment with cholecalciferol, parallel with energy restriction $(-700 \mathrm{kcal} ;-2930 \mathrm{~kJ})$ resulted in a more pronounced decrease in TAG concentration $(-13.5 \%$ compared with $+3 \%)$, and an increase in LDLcholesterol than did energy restriction alone. These beneficial effects on TAG concentration were independent of body weight, fat mass and sex. However, supplementation for 1 year with either 10 or $20 \mu \mathrm{g}$ cholecalciferol in healthy Pakistani immigrants living in Denmark had no effect on total cholesterol, HDL-cholesterol, LDL-cholesterol or VLDL-cholesterol, the LDL:HDL ratio, or TAG concentration $^{(161)}$, although the doses were probably not sufficient to achieve a clinically meaningful effect on lipids. At similar doses of between 5 and $15 \mu \mathrm{g} / \mathrm{d}$, we showed no effect of cholecalciferol supplementation during the winter on lipids (S Muldowney, TR Hill, AJ Lucey, et al., unpublished results) in adults aged 20-40 and $>65$ years. On the basis of these data, future interventions need to use doses of vitamin $\mathrm{D}$ to achieve targeted s25(OH)D levels, which may have a beneficial effect on lipids. Four other RCT which reported insulin sensitivity/ release or blood pressure as the primary outcome reported no effects on lipids ${ }^{(83,85,86,139)}$.

All other RCT investigating effects of cholecalciferol on lipids also gave $\mathrm{Ca}^{(89,109,162-164)}$. Gannage-Yared et al. ${ }^{(162)}$ observed no effect of $1 \mathrm{~g}$ Ca plus $20 \mu \mathrm{g}$ cholecalciferol on LDL-cholesterol, or HDL-cholesterol or TAG concentration in postmenopausal women ( $n$ 39); however, this was a short-term trial of 12 weeks with a small number of subjects. Using data from the Women's Health Initiative, Rajpathak et al. ${ }^{(163)}$ observed no significant effect of $1 \mathrm{~g}$ Ca plus $10 \mu \mathrm{g}$ cholecalciferol on circulating lipids after 5 years. Major et al. ${ }^{(109)}$ showed that $1200 \mathrm{mg}$ Ca plus $10 \mu \mathrm{g}$ cholecalciferol for 15 weeks lowered total cholesterol:HDL and LDL:HDL ratios and LDL-cholesterol concentrations compared with placebo. These effects were independent of fat mass and waist circumference for the total cholesterol:HDL and LDL:HDL ratio but not for LDLcholesterol. A recent RCT in which 140 men $>50$ years were randomised to receive either milk ( $400 \mathrm{ml}$ of $1 \%$ fat fortified with $1 \mathrm{~g} \mathrm{Ca}$ and $20 \mu \mathrm{g}$ vitamin $\mathrm{D}_{3}$ ) or no milk for 2 years showed no effect on total cholesterol, HDLcholesterol, or LDL-cholesterol, or TAG concentration ${ }^{(164)}$. Jorde et al. ${ }^{(89)}$ showed that $500 \mathrm{mg}$ Ca per d plus 500 or $1000 \mu \mathrm{g}$ cholecalciferol per week had no effect on lipid profiles after 1 year in 334 overweight and obese subjects.

For many years, treatment for psoriasis has included climate therapy. Osmancevic et al. ${ }^{(165)}$ showed that psoriasis symptoms improved in twenty patients aged 25-65 years with $15 \mathrm{~d}$ of climate therapy in Gran Canaria. The LDL:HDL ratio decreased from 2.4 to $1.9 \mathrm{mmol} / 1$
$(P<0.001)$, apoA1 and HDL-cholesterol concentration increased and apoB decreased during the sun exposure period. However, there was no effect on either total or LDL-cholesterol. In contrast, Carbone et al. ${ }^{(158)}$ showed in young healthy adults ( $n$ 49) that UVB radiation had no effect on any lipoproteins or apolipoproteins. However, in this study, subgroup analysis showed differential effects of UVB radiation on lipids and lipoproteins according to baseline s25 $(\mathrm{OH}) \mathrm{D}$ concentrations, providing additional evidence for using a modified study design which seeks to achieve specific 25(OH)D levels and accounts for baseline levels in the data analysis.

There is some evidence that vitamin D may have a negative effect on lipids, particularly HDL-cholesterol, which requires further exploration. Postmenopausal women ( $n$ 402) in the Kuopio Osteoporosis Study were randomised to receive one of four treatments: (a) sequential combination of $2 \mathrm{mg}$ oestradiol valerate and $1 \mathrm{mg}$ cyproterone acetate (hormone replacement therapy); (b) $7.5 \mu \mathrm{g}$ cholecalciferol; (c) hormone replacement therapy and $7.5 \mu \mathrm{g}$ cholecalciferol; (d) placebo ${ }^{(166)}$. Both the cholecalciferol and placebo groups received $500 \mathrm{mg}$ calcium lactate. The hormone replacement therapy treatment reduced serum total cholesterol, most probably due to the decrease in LDL-cholesterol; however, cholecalciferol supplementation increased LDL-cholesterol by $6 \%$ in the 1 -year period. In the follow-up study, Heikkinen et al. ${ }^{(167)}$ observed that cholecalciferol supplementation over 3 years lowered HDL-cholesterol. However, as this reduction was also observed in the placebo group, it may not have been an effect of vitamin D. A recent study showed that VDR knock-out mice had higher total and HDL-cholesterol than wild-type mice ${ }^{(168)}$. The higher HDL-cholesterol concentration was only apparent in males ${ }^{(168)}$ and requires replication in further studies before being acknowledged as a real effect. If vitamin $\mathrm{D}$ has a negative effect on HDL-cholesterol it may be a consequence of suppressive effects of $1,25(\mathrm{OH})_{2} \mathrm{D}$ on apoA1 gene expression, possibly by altering co-activators and co-repressors ${ }^{(169)}$. Overall, the evidence for a beneficial or negative effect of vitamin $\mathrm{D}$ on lipids requires much further exploration. With regard to total cholesterol, LDL-cholesterol and TAG, the evidence leans towards a beneficial association whereas the data on HDL-cholesterol are conflicting.

\section{Inflammation}

Obesity induces a chronic inflammatory environment, which is implicated in metabolic dysfunction and CVD $^{(170-172)}$. Pro-inflammatory cytokines include IL-1, IL-6 and TNF- $\alpha^{(173)}$, whereas IL-10 has an anti-inflammatory effect $^{(174)}$. C-reactive protein (CRP), an acute-phase reactant, is a clinically validated and widely measured marker of systemic inflammation and increased synthesis can be stimulated by IL- 6 and TNF- $\alpha$. Certain inflammatory cytokines and CRP levels are elevated in adults with obesity, CVD, 
type 2 diabetes and the MetS ${ }^{(170,171,175,176)}$. Accumulating evidence for an important role for vitamin $\mathrm{D}$ in regulation both of the adaptive and innate immune systems has led to intense interest in this field. Potent immunoregulatory effects of $1,25(\mathrm{OH})_{2} \mathrm{D}$ include anti-proliferative properties, stimulation of production of cathelicidin by macrophages and bacterial killing and modulation of B-and T-lymphocyte proliferation and function ${ }^{(177)}$. Most exciting about the recent discoveries is the role for $25(\mathrm{OH}) \mathrm{D}$ in induction of these effects, which means that the potential impact on human health by improving host defence and modulating the inflammatory response is immense ${ }^{(178)}$.

Immune cells not only express the VDR but also CYP27B1 $1^{(179,180)}$, allowing them to synthesise and secrete $1,25(\mathrm{OH})_{2} \mathrm{D}$ in a regulated fashion ${ }^{(181)}$. Crucially, as this occurs in an autocrine fashion and not under endocrine control, vitamin D-inactivating hydroxylase is also expressed, which helps to temper the local effects of $1,25(\mathrm{OH})_{2} \mathrm{D}$, preventing potential damage caused by over-stimulation of the immune system ${ }^{(177,182)} \cdot 1,25(\mathrm{OH})_{2} \mathrm{D}$ uses several different molecular mechanisms to regulate cytokine expression, either directly by targeting transcription initiation and regulation or indirectly interfering with other intracellular signalling pathways ${ }^{(183)}$. The $1,25(\mathrm{OH})_{2} \mathrm{D} / \mathrm{VDR} / \mathrm{RXR}$ complex can occupy the nuclear factor of activated $\mathrm{T}$ cells at the nuclear factor of activated $\mathrm{T}$ cells- 1 site, in the promoter region of some cytokines, thereby preventing T cell-specific transcription factor forming a complex with activator protein 1 , which is necessary for cytokine production ${ }^{(184)}$. Zhu et al. ${ }^{(185)}$ showed that in colonic tissue of IL-10 knock-out mice with inflammatory bowel disease, $1,25(\mathrm{OH})_{2} \mathrm{D}$ was capable of down-regulating several genes associated with TNF- $\alpha$, including TNF- $\alpha$ receptor 1 , proteins involved in the transcription of TNF- $\alpha$, and TNF- $\alpha$ itself. As well as direct effects, vitamin D could exert beneficial effects on cytokine production indirectly by maintaining serum $\mathrm{Ca}$ concentrations; in human umbilical vein cord endothelial cells, hypocalcaemia up-regulated endothelial NF- $\mathrm{KB}$ activity and IL-6 concentration was elevated ${ }^{(186)}$. In addition, PTH induces IL-6 synthesis in osteoblasts ${ }^{(187)}$.

Clinical data. Data examining the associations between vitamin $\mathrm{D}$ and inflammation in relation to CVD are limited and the data are conflicting. In type 2 diabetics ( $n$ 459), CRP concentration was higher in those with a s25 $(\mathrm{OH}) \mathrm{D}<50$ compared with those above $50 \mathrm{nmol} / \mathrm{l}^{(156)}$. A cross-sectional analysis of the Framingham Offspring Study ( $n$ 1381; aged 35-89 years) showed that plasma $25(\mathrm{OH}) \mathrm{D}$ was not associated with overall inflammation, indicated by the inflammation index, sum of the fourteen individual markers of inflammation used in the study ${ }^{(188)}$. In addition, plasma $25(\mathrm{OH}) \mathrm{D}$ was not associated with any of the individual markers except IL-6 $(P=0.02)$. Peterson \& Heffernan ${ }^{(189)}$ showed in healthy women ( $n$ 69), aged 25-82 years, that s25(OH)D concentration was inversely associated with TNF- $\alpha$ but no association was apparent between s25(OH)D and IL-6, IL-10 or CRP. Unexpectedly, we showed in young overweight adults that having a s25(OH)D concentration $<50 \mathrm{nmol} / 1$ decreased the likelihood (OR 0.35; $95 \%$ CI $0.17,0.73$ ) of having an elevated CRP concentration(S Muldowney, A Lucey, G Paschos, et al., unpublished results).

Intervention trials. Data from RCT looking at the effects of vitamin $\mathrm{D}_{3}$ (as a single treatment) on inflammatory cytokines or CRP in healthy subjects are meagre. Most of the evidence comes from studies where participants have underlying conditions, or vitamin D deficiency (see Table 1). A total of twenty-two intensive care unit patients were randomised to receive daily either $5 \mu \mathrm{g}$ (low dose) or $12.5 \mu \mathrm{g}$ (high dose) for $10 \mathrm{~d}$ and compared with healthy age-, sex- and BMI-matched controls ${ }^{(190)}$. While treatment had no effect on TNF- $\alpha$ or IL-1, the reduction in CRP was greater in the high-dose group compared with the low-dose group, and a reduction in IL- 6 was only apparent in the high-dose group. Timms et al. ${ }^{(71)}$ randomised healthy British adults of Bangladeshi origin, with vitamin D deficiency ( $\mathrm{s} 25(\mathrm{OH}) \mathrm{D}<27.5 \mathrm{nmol} / \mathrm{l}$ ), to receive 3 -monthly injections of an oily cholecalciferol solution $(1250 \mu \mathrm{g}$ or $12.5 \mu \mathrm{g})$ for 1 year. The two treatment groups were combined and CRP concentration was dramatically reduced post-supplementation $(-23 \%)$. In the Zittermann et al. ${ }^{(111)}$ weight-loss study, compared with placebo, vitamin D supplementation decreased TNF- $\alpha$ concentration, whereas there was no effect on CRP or IL-6 concentration in either group. Most recently, eighty-one South Asian women living in New Zealand, who were insulin resistant and had a s25(OH)D $<50 \mathrm{nmol} / \mathrm{l}$, were randomised to receive either $100 \mu \mathrm{g}$ cholecalciferol or a placebo daily for 6 months; however, no effect on CRP was apparent ${ }^{(85)}$. Similarly, we observed no effect on CRP after 6 months of cholecalciferol supplementation in healthy adults (S Muldowney, TR Hill, AJ Lucey, et al., unpublished results).

To the best of our knowledge all other vitamin D RCT looking at its effects on inflammatory markers were in combination with $\mathrm{Ca}$. Schleithoff et $a l^{(191)}$ supplemented congestive heart failure patients ( $($ 93) with $500 \mathrm{mg} \mathrm{Ca}$ combined with either $50 \mu \mathrm{g}$ cholecalciferol daily or a placebo for 9 months. In patients who received vitamin $\mathrm{D}$ a reduction in TNF- $\alpha$ concentration was apparent; in addition, IL-10 concentration was increased. Multiple sclerosis patients ( $n$ 39) with a s25(OH)D concentration $<50$ $\mathrm{nmol} / 1$ were randomised to receive daily $800 \mathrm{mg}$ Ca plus placebo or $800 \mathrm{mg}$ Ca plus $25 \mu \mathrm{g}$ cholecalciferol for 6 months ${ }^{(192)}$. Vitamin D supplementation increased serum concentrations of transforming growth factor- $\beta 1$, an antiinflammatory cytokine, whereas there was no effect in the placebo group. However, mRNA levels of TNF- $\alpha$, IL-2, interferon- $\gamma$ and IL-13 concentrations did not change in either group. In a double-blind randomised study, where non-diabetic elderly adults (aged $>65$ years) were given either $500 \mathrm{mg} \mathrm{Ca}$ and $17.5 \mu \mathrm{g}$ cholecalciferol or a 
placebo, no effect on CRP or IL-6 concentration was observed over 3 years in either subjects with impaired fasting glucose or normal fasting glucose concentrations ${ }^{(87)}$. A short-term supplementation trial (12-week duration) with $1000 \mathrm{mg} \mathrm{Ca}$ and $20 \mu \mathrm{g}$ cholecalciferol daily of postmenopausal women ( $n$ 39) had no effect on circulating concentrations of IL-6, TNF- $\alpha$ or $\mathrm{CRP}^{(161)}$. More recently, a large RCT on overweight and obese subjects ( $n$ 334) showed no effect of supplementation with $\mathrm{Ca}(500 \mathrm{mg} / \mathrm{d})$ plus cholecalciferol (500 or $1000 \mu \mathrm{g} /$ week) for 1 year on a wide range of cytokines and other inflammatory markers ${ }^{(193)}$.

In brief, there appears to be no effect of supplementation in healthy adults (S Muldowney, TR Hill, AJ Lucey, et al., unpublished results; Pittas et al. ${ }^{(87)}$; Jorde et $a l .{ }^{(89)}$; Gannage-Yared et al. ${ }^{(162)}$; unless vitamin D deficient at baseline ${ }^{(71)}$, this may be related to the low circulating concentration of the cytokines in healthy subjects. Furthermore, the studies by Schleithoff et al. ${ }^{(191)}$ and Mahon et al. ${ }^{(192)}$ suggest that a high requirement of vitamin $\mathrm{D}(>25 \mu \mathrm{g} / \mathrm{d})$ is needed to mediate its immunological protective effects.

\section{Novel markers of CVD risk}

Adhesion molecules, PAI-1 and matrix metalloproteinases (MMP) and their inhibitors can be used as markers of CVD risk and, recently, have been associated with vitamin D status. The adhesion molecules, such as intracellularand vascular-cell adhesion molecules, mediate the migration of inflammatory cells to atherosclerotic lesions. They act as ligands to tightly bind various molecules in the inflammatory process. A small number of studies, with conflicting results, have shown a relationship between vitamin $\mathrm{D} \quad\left(1,25(\mathrm{OH})_{2} \mathrm{D}\right)$ and the adhesion molecules $^{(194-197)}$. The positive effect is most probably mediated through $1,25(\mathrm{OH})_{2} \mathrm{D}$ action on suppressing TNF- $\alpha$ secretion ${ }^{(190)}$, but further studies are required to elucidate this relationship further.

PAI-1, which is produced by the vascular endothelium and platelets, is an important regulator of fibrinolysis ${ }^{(198)}$ as it rapidly binds, and therefore inhibits, tissue plasminogen activator and urinary plasminogen activator. High PAI-1 concentrations have been shown to predict first occurrence of a myocardial infarction ${ }^{(199)}$, or reoccurrence before the age of 45 years ${ }^{(200,201)}$. Studies have found that $1,25(\mathrm{OH})_{2} \mathrm{D}$ reduces PAI- 1 concentrations in various cell types, including vascular cells and smooth-muscle cells $^{(202,203)}$. A possible mechanism for the association between PAI-1 and vitamin D may be similar to blood pressure, which involves the RAS. Angiotensin II stimulates the production of PAI-1 in cultured endothelial and vascular smooth-muscle cells ${ }^{(204)}$, whereas the inhibition of angiotensin-converting enzyme is associated with a decrease in both plasma PAI-1 concentrations and PAI-1 activity $^{(205)}$. Recently, a large RCT with Ca $(500 \mathrm{mg}$ daily plus cholecalciferol at 500 or $1000 \mu \mathrm{g} /$ week) for 1 year showed no effect on PAI-1 or other haemostatic markers in overweight and obese subjects ${ }^{(206)}$. However, evidence is limited and more studies (cross-sectional, interventional and mechanistic) are required.

MMP are a family of $\mathrm{Zn}$-containing enzymes that have an important role in extracellular matrix degradation, synthesis and remodelling ${ }^{(207)}$. MMP are activated by MMP proenzymes and inhibited by endogenous tissue inhibitors of metalloproteinases (TIMP) and the net proteolytic activity is a function of the balance of MMP to TIMP. MMP degradation of the extracellular matrix may assist the influx of leucocytes through the endothelial layer, contributing to a decrease in endothelial barrier function, and facilitate migration of vascular smooth muscle cells into the intimal space where they proliferate and contribute to plaque formation ${ }^{(172,208)}$. MMP-9 and TIMP-1 have been identified as novel predictors of CVD risk. Experimental studies (either animal or cell) have shown that $1,25(\mathrm{OH})_{2} \mathrm{D}$ regulates MMP expression ${ }^{(118,207,209)}$. Rahman et $a$. $^{(207)}$ showed that TIMP-1 and TIMP-3 were significantly under-expressed, while MMP-2 and MMP-9 were up-regulated in the cardiac tissue of VDR knock-out mice as compared with wild-type mice. However, human studies supporting an association between vitamin $\mathrm{D}$ and the MMP/TIMP system in humans are limited. A cross-sectional study, ran in tangent with an intervention study on healthy Bangladeshi adults living in Britain ( $n$ 171; aged 35-65 years), who were vitamin $\mathrm{D}$ deficient $(\mathrm{s} 25(\mathrm{OH}) \mathrm{D}<27.5$ $\mathrm{nmol} / \mathrm{l}$ ) showed that vitamin D status was an independent predictor of MMP-9 concentration and a reduction in MMP$9(66.8 \%)$ and TIMP-1 (39.8\%) concentration was apparent following vitamin D supplementation ${ }^{(71)}$.

\section{Summary and future directions}

There is a considerable body of evidence from crosssectional and prospective studies showing that low vitamin $\mathrm{D}$ status is associated with an increased risk of CVD, the MetS and each of its individual risk factors. Furthermore, there are strong mechanistic data to support the role of vitamin D in the reduction of CVD risk factors, particularly for insulin secretion, insulin resistance and hypertension mediated by the RAS. Evidence is not as robust for the association between vitamin D status and dyslipidaemia and further studies are required. Data from RCT are relatively rare and are confounded by inappropriate study design, inadequate characterisation of subjects, lack of data on season and sunshine exposure and interventions combining $\mathrm{Ca}$ and vitamin $\mathrm{D}$.

If vitamin D influences cardiometabolic health, these effects may only be measurable at higher doses than those achievable through diet. This raises several questions about the food/pharma interface with respect to nutrition interventions, the impact that high dose studies have on skewing the literature and how such data should be considered when dietary recommendations are under review. 
With the notable exception of folic acid, where supplemental approaches are required to achieve the maximum benefit, nutritional science so far has relied on food-based approaches to achieve optimal health through diet. However, increasing confidence about the safety of vitamin $\mathrm{D}$ doses in excess of the current tolerable upper intake levels should enable further RCT to be implemented using vitamin $\mathrm{D}$ as a single treatment at doses calibrated to achieve target thresholds of s25(OH)D concentrations, particularly in vitamin D-deficient individuals or patient subgroups with elevated CVD risk biomarkers.

\section{Acknowledgements}

The present review received no specific grant from any funding agency in the public, commercial or not-forprofit sectors.

Three studies submitted for publication have been included as unpublished results. These are: Muldowney S, Lucey A, Paschos G, et al. 'Vitamin D status and cardio-metabolic risk factors in young European adults'; Kiely M, Muldowney S, Hill TR, et al. 'Vitamin D status and cardio-metabolic risk factors in adolescents'; Muldowney S, Hill TR, Lucey AJ, et al. 'Effect of vitamin D supplementation on biomarkers of CVD risk in 20-40 and $64+$ year old men and women'.

Both authors contributed equally to the drafting and editing of the manuscript.

The authors have no conflict of interest.

\section{References}

1. Lloyd-Jones D, Adams R, Carnethon M, et al. (2009) Heart Disease and Stroke Statistics - 2009 Update: A Report From the American Heart Association Statistics Committee and Stroke Statistics Subcommittee. Circulation 119, e21-e181.

2. Central Statistics Office (2007) Deaths from Principal Causes Registered in the Years 1998 to 2005. Cork, Republic of Ireland: Central Statistics Office.

3. Thom T, Haase N, Rosamond W, et al. (2006) Heart disease and stroke statistics - 2006 update: a report from the American Heart Association Statistics Committee and Stroke Statistics Subcommittee. Circulation 113, e85-e151.

4. Yusuf SH, Hawken S, Ounpuu S, et al. (2004) Effect of potentially modifiable risk factors associated with myocardial infarction in 52 countries (the INTERHEART study): case-control study. Lancet 364, 937-952.

5. Kylin E (1923) Studien uber das Hypertonie-Hyperglyka 'mie-Hyperurika' Miesyndrom (Studies of the hypertension-hyperglycemia-hyperuricemia syndrome). Zentralbl Inn Med 44, 105-127.

6. Ford ES, Giles WH \& Dietz WH (2002) Prevalence of the metabolic syndrome among US adults: findings from the third National Health and Nutrition Examination Survey. JAMA 287, 356-359.

7. Hu G, Qiao Q, Tuomilehto J, et al. (2004) Prevalence of the metabolic syndrome and its relation to all-cause and cardiovascular mortality in nondiabetic European men and women. Arch Intern Med 164, 1066-1076.

8. Villegas RP, Perry IJ, Creagh D, et al. (2003) Prevalence of the metabolic syndrome in middle-aged men and women. Diabetes Care 26, 3198-3199.

9. World Health Organization (1999) Definition, Diagnosis and Classification of Diabetes Mellitus and its Complications. Geneva: Department of Noncommunicable Disease Surveillance.

10. National Institutes of Health (2001) Third Report of the National Cholesterol Education Program Expert Panel on Detection, Evaluation, and Treatment of High Blood Cholesterol in Adults (Adult Treatment Panel III): Executive Summary. Bethesda, MD: National Institutes of Health.

11. Ford ES, Ajani UA, McGuire LC, et al. (2005) Concentrations of serum vitamin $\mathrm{D}$ and the metabolic syndrome among U.S. adults. Diabetes Care 28, 1228-1230.

12. Dobnig H, Pilz S, Scharnagl H, et al. (2008) Independent association of low serum 25-hydroxyvitamin D and 1,25dihydroxyvitamin D levels with all-cause and cardiovascular mortality. Arch Intern Med 168, 1340-1349.

13. Holick MF, Biancuzzo RM, Chen TC, et al. (2008) Vitamin $\mathrm{D}_{2}$ is as effective as vitamin $\mathrm{D}_{3}$ in maintaining circulating concentrations of 25-hydroxyvitamin D. J Clin Endocrinol Metab 93, 677-681.

14. Abdelkefi A, Achour W, Ben Othman T, et al. (2007) Use of heparin-coated central venous lines to prevent catheterrelated bloodstream infection. J Support Oncol 5, 273-278.

15. Holick MF (2004) Vitamin D: importance in the prevention of cancers, type 1 diabetes, heart disease, and osteoporosis. Am J Clin Nutr 79, 362-371.

16. Haussler MR, Whitfield GK, Haussler CA, et al. (1998) The nuclear vitamin D receptor: biological and molecular regulatory properties revealed. J Bone Miner Res 13, 325-349.

17. Zittermann A (2003) Vitamin D in preventive medicine: are we ignoring the evidence? Br J Nutr 89, 552-572.

18. Hass GM, Landerholm W \& Hemmens A (1966) Production of calcific athero-arteriosclerosis and thromboarteritis with nicotine, vitamin D and dietary cholesterol. Am J Pathol 49, 739-771.

19. Eisenstein R, Ellis H \& Rosato J (1969) In vitro studies of vitamin D-induced aortic calcification. Proc Soc Exp Biol Med 132, 58-62.

20. Morrison LM, Bajwa GS, Alfin-Slater RB, et al. (1972) Prevention of vascular lesions by chondroitin sulfate $\mathrm{A}$ in the coronary artery and aorta of rats induced by a hypervitaminosis D, cholesterol-containing diet. Atherosclerosis 16, $105-118$.

21. Linden V (1974) Vitamin D and myocardial infarction. $B r$ Med J 3, 647-650.

22. Schmidt-Gayk H, Goossen J, Lendle F, et al. (1977) Serum 25 -hydroxycalciferol in myocardial infarction. Atherosclerosis 26, 55-58.

23. Vik B, Try K, Thelle DS, et al. (1979) Tromso Heart Study: vitamin D metabolism and myocardial infarction. Br Med J 2, 176.

24. Zittermann A \& Koerfer R (2008) Vitamin D in the prevention and treatment of coronary heart disease. Curr Opin Clin Nutr Metab Care 11, 752-757.

25. Zittermann A, Schleithoff SS \& Koerfer R (2005) Putting cardiovascular disease and vitamin $\mathrm{D}$ insufficiency into perspective. Br J Nutr 94, 483-492.

26. Grimes DS, Hindle E \& Dyer T (1996) Sunlight, cholesterol and coronary heart disease. Q J Med 89, 579-590.

27. Giovannucci E, Liu Y, Hollis BW, et al. (2008) 25-Hydroxyvitamin $D$ and risk of myocardial infarction in men: a prospective study. Arch Intern Med 168, 1174-1180. 
28. Trivedi DP, Doll R \& Khaw KT (2003) Effect of four monthly oral vitamin $\mathrm{D}_{3}$ (cholecalciferol) supplementation on fractures and mortality in men and women living in the community: randomised double blind controlled trial. BMJ 326, 469.

29. Hsia J, Heiss G, Ren H, et al. (2007) Calcium/vitamin D supplementation and cardiovascular events. Circulation 115, $846-854$

30. LaCroix AZ, Kotchen J, Anderson G, et al. (2009) Calcium plus vitamin D supplementation and mortality in postmenopausal women: the Women's Health Initiative calciumvitamin D randomized controlled trial. J Gerontol A Biol Sci Med Sci 64, 559-567.

31. Prince RL, Austin N, Devine A, et al. (2008) Effects of ergocalciferol added to calcium on the risk of falls in elderly high-risk women. Arch Intern Med 168, 103-108.

32. Bolland MJ, Avenell A, Baron JA, et al. (2010) Effect of calcium supplements on risk of myocardial infarction and cardiovascular events: meta analysis. BMJ 341, c3691.

33. Alberti KG, Zimmet P \& Shaw J (2005) The metabolic syndrome - a new worldwide definition. Lancet 366, 1059-1062.

34. Einhorn D, Reaven GM, Cobin RH, et al. (2003) American College of Endocrinology position statement on the insulin resistance syndrome. Endocr Pract 9, 237-252.

35. Grundy SM, Cleeman JI, Daniels SR, et al. (2005) Diagnosis and management of the metabolic syndrome. An American Heart Association/National Heart, Lung, and Blood Institute Scientific Statement. Executive summary. Cardiol Rev 13, 322-327.

36. Isomaa B, Almgren P, Tuomi T, et al. (2001) Cardiovascular morbidity and mortality associated with the metabolic syndrome. Diabetes Care 24, 683-689.

37. Forouhi NG, Luan J, Cooper A, et al. (2008) Baseline serum 25-hydroxy vitamin $D$ is predictive of future glycemic status and insulin resistance: the Medical Research Council Ely Prospective Study 1990-2000. Diabetes 57, 2619-2625.

38. Hypponen E, Boucher BJ, Berry DJ, et al. (2008) 25-Hydroxyvitamin D, IGF-1, and metabolic syndrome at 45 years of age: a cross-sectional study in the 1958 British Birth Cohort. Diabetes 57, 298-305.

39. Reis JP, von Muhlen D \& Miller ER III (2008) Relation of 25hydroxyvitamin $\mathrm{D}$ and parathyroid hormone levels with metabolic syndrome among US adults. Eur J Endocrinol 159, 41-48.

40. Hjelmesaeth J, Hofso D, Aasheim ET, et al. (2009) Parathyroid hormone, but not vitamin $\mathrm{D}$, is associated with the metabolic syndrome in morbidly obese women and men: a cross-sectional study. Cardiovasc Diabetol 8, 7.

41. McGill AT, Stewart JM, Lithander FE, et al. (2008) Relationships of low serum vitamin $\mathrm{D}_{3}$ with anthropometry and markers of the metabolic syndrome and diabetes in overweight and obesity. Nutr J 7, 4.

42. Reis JP, von Muhlen D, Kritz-Silverstein D, et al. (2007) Vitamin $\mathrm{D}$, parathyroid hormone levels, and the prevalence of metabolic syndrome in community-dwelling older adults. Diabetes Care 30, 1549-1555.

43. Parker J, Hashmi O, Dutton D, et al. (2010) Levels of vitamin D and cardiometabolic disorders: systematic review and meta-analysis. Maturitas 65, 225-236.

44. Weyer C, Bogardus C \& Pratley RE (1999) Metabolic factors contributing to increased resting metabolic rate and decreased insulin-induced thermogenesis during the development of type 2 diabetes. Diabetes 48, 1607-1614.

45. Pittas AG, Lau J, Hu FB, et al. (2007) The role of vitamin D and calcium in type 2 diabetes. A systematic review and meta-analysis. J Clin Endocrinol Metab 92, 2017-2029.
46. Teegarden D \& Donkin SS (2009) Vitamin D: emerging new roles in insulin sensitivity. Nutr Res Rev 22, 82-92.

47. Bland R, Markovic D, Hills CE, et al. (2004) Expression of 25 -hydroxyvitamin $\mathrm{D}_{3}-1 \alpha$-hydroxylase in pancreatic islets. J Steroid Biochem Mol Biol 89-90, 121-125.

48. Zeitz U, Weber K, Soegiarto DW, et al. (2003) Impaired insulin secretory capacity in mice lacking a functional vitamin D receptor. FASEB J 17, 509-511.

49. Bourlon PM, Billaudel B \& Faure-Dussert A (1999) Influence of vitamin $\mathrm{D}_{3}$ deficiency and 1,25 dihydroxyvitamin $\mathrm{D}_{3}$ on de novo insulin biosynthesis in the islets of the rat endocrine pancreas. J Endocrinol 160, 87-95.

50. Arnold BM, Kuttner M, Swaminathan R, et al. (1975) Radioimmunoassay studies of intestinal calcium-binding protein in the pig. I. Identification of intestinal calcium-binding protein in blood and response to a low calcium diet. Can $J$ Physiol Pharmacol 53, 1129-1134.

51. Morrissey RL, Bucci TJ, Richard B, et al. (1975) Calciumbinding protein: its cellular localization in jejunum, kidney and pancreas. Proc Soc Exp Biol Med 149, 56-60.

52. Sooy K, Schermerhorn T, Noda M, et al. (1999) Calbindin$\mathrm{D}_{28 \mathrm{k}}$ controls $\left[\mathrm{Ca}^{(2+)}\right]_{i}$ and insulin release. Evidence obtained from calbindin- $\mathrm{D}_{28 \mathrm{k}}$ knockout mice and $\beta$ cell lines. J Biol Chem 274, 34343-34349.

53. Chiu KC, Chu A, Go VL, et al. (2004) Hypovitaminosis D is associated with insulin resistance and $\beta$ cell dysfunction. Am J Clin Nutr 79, 820-825.

54. Calle C, Maestro B \& Garcia-Arencibia M (2008) Genomic actions of 1,25-dihydroxyvitamin $\mathrm{D}_{3}$ on insulin receptor gene expression, insulin receptor number and insulin activity in the kidney, liver and adipose tissue of streptozotocin-induced diabetic rats. BMC Mol Biol 9, 65.

55. Chiu KC, Chuang LM, Lee NP, et al. (2000) Insulin sensitivity is inversely correlated with plasma intact parathyroid hormone level. Metabolism 49, 1501-1505.

56. McCarty MF \& Thomas CA (2003) PTH excess may promote weight gain by impeding catecholamine-induced lipolysis - implications for the impact of calcium, vitamin D, and alcohol on body weight. Med Hypotheses 61, 535-542.

57. Wareham NJ, Byrne CD, Carr C, et al. (1997) Glucose intolerance is associated with altered calcium homeostasis: a possible link between increased serum calcium concentration and cardiovascular disease mortality. Metabolism 46, 1171-1177.

58. Snijder M, van Dam R, Visser M, et al. (2006) To: Mathieu C, Gysemans C, Giulietti A, Bouillon R (2005) Vitamin D and diabetes. Diabetologia 48, 1247-1257. Diabetologia 49, 217-218.

59. Reis AF, Hauache OM \& Velho G (2005) Vitamin D endocrine system and the genetic susceptibility to diabetes, obesity and vascular disease. A review of evidence. Diabetes Metab 31, 318-325.

60. Palomer X, Gonzalez-Clemente JM, Blanco-Vaca F, et al. (2008) Role of vitamin D in the pathogenesis of type 2 diabetes mellitus. Diabetes Obes Metab 10, 185-197.

61. Dilmec F, Uzer E, Akkafa F, et al. (2010) Detection of VDR gene ApaI and TaqI polymorphisms in patients with type 2 diabetes mellitus using PCR-RFLP method in a Turkish population. J Diabetes Complications 24, 186-191.

62. Ye WZ, Dubois-Laforgue D, Bellanne-Chantelot C, et al. (2001) Variations in the vitamin D-binding protein (Gc locus) and risk of type 2 diabetes mellitus in French Caucasians. Metabolism 50, 366-369.

63. Malecki MT, Frey J, Moczulski D, et al. (2003) Vitamin D receptor gene polymorphisms and association with type 2 diabetes mellitus in a Polish population. Exp Clin Endocrinol Diabetes 111, 505-509. 
64. Hitman GA, Mannan N, McDermott MF, et al. (1998) Vitamin D receptor gene polymorphisms influence insulin secretion in Bangladeshi Asians. Diabetes 47, 688-690.

65. Ogunkolade BW, Boucher BJ, Prahl JM, et al. (2002) Vitamin $D$ receptor (VDR) mRNA and VDR protein levels in relation to vitamin D status, insulin secretory capacity, and VDR genotype in Bangladeshi Asians. Diabetes 51, 2294-2300.

66. Oh JY \& Barrett-Connor E (2002) Association between vitamin D receptor polymorphism and type 2 diabetes or metabolic syndrome in community-dwelling older adults: the Rancho Bernardo Study. Metabolism 51, 356-359.

67. Tworowska-Bardzinska U, Lwow F, Kubicka E, et al. (2008) The vitamin D receptor gene BsmI polymorphism is not associated with anthropometric and biochemical parameters describing metabolic syndrome in postmenopausal women. Gynecol Endocrinol 24, 514-518.

68. Chiu KC, Chuang LM \& Yoon C (2001) The vitamin D receptor polymorphism in the translation initiation codon is a risk factor for insulin resistance in glucose tolerant Caucasians. BMC Med Genet $\mathbf{2}, 2$.

69. Filus A, Trzmiel A, Kuliczkowska-Plaksej J, et al. (2008) Relationship between vitamin D receptor BsmI and FokI polymorphisms and anthropometric and biochemical parameters describing metabolic syndrome. Aging Male 11, 134-139.

70. Tai K, Need AG, Horowitz M, et al. (2008) Vitamin D, glucose, insulin, and insulin sensitivity. Nutrition 24, 279-285.

71. Timms PM, Mannan N, Hitman GA, et al. (2002) Circulating MMP9, vitamin D and variation in the TIMP-1 response with VDR genotype: mechanisms for inflammatory damage in chronic disorders? QJM 95, 787-796.

72. Duncan BB, Schmidt MI, Pankow JS, et al. (2003) Lowgrade systemic inflammation and the development of type 2 diabetes: the atherosclerosis risk in communities study. Diabetes 52, 1799-1805.

73. Pradhan AD, Manson JE, Rifai N, et al. (2001) C-reactive protein, interleukin 6 , and risk of developing type 2 diabetes mellitus. JAMA 286, 327-334.

74. Giulietti A, van Etten E, Overbergh L, et al. (2007) Monocytes from type 2 diabetic patients have a pro-inflammatory profile. 1,25-Dihydroxyvitamin $\mathrm{D}_{3}$ works as anti-inflammatory. Diabetes Res Clin Pract 77, 47-57.

75. Choi HK, Willett WC, Stampfer MJ, et al. (2005) Dairy consumption and risk of type 2 diabetes mellitus in men: a prospective study. Arch Intern Med 165, 997-1003.

76. Liu S, Song Y, Ford ES, et al. (2005) Dietary calcium, vitamin $\mathrm{D}$, and the prevalence of metabolic syndrome in middleaged and older U.S. women. Diabetes Care 28, 2926-2932.

77. Liu S, Choi HK, Ford E, et al. (2006) A prospective study of dairy intake and the risk of type 2 diabetes in women. Diabetes Care 29, 1579-1584.

78. Pittas AG, Dawson-Hughes B, Li T, et al. (2006) Vitamin D and calcium intake in relation to type 2 diabetes in women. Diabetes Care 29, 650-656.

79. Scragg R, Sowers M \& Bell C (2004) Serum 25-hydroxyvitamin D, diabetes, and ethnicity in the Third National Health and Nutrition Examination Survey. Diabetes Care 27, $2813-2818$.

80. Liu E, Meigs JB, Pittas AG, et al. (2009) Plasma 25-hydroxyvitamin $\mathrm{D}$ is associated with markers of the insulin resistant phenotype in nondiabetic adults. J Nutr 139, 329-334.

81. Scragg R, Holdaway I, Singh V, et al. (1995) Serum 25hydroxyvitamin $\mathrm{D}_{3}$ levels decreased in impaired glucose tolerance and diabetes mellitus. Diabetes Res Clin Pract 27, 181-188.

82. Hypponen E \& Power C (2006) Vitamin D status and glucose homeostasis in the 1958 British birth cohort: the role of obesity. Diabetes Care 29, 2244-2246.
83. Nagpal J, Pande JN \& Bhartia A (2009) A double-blind, randomized, placebo-controlled trial of the short-term effect of vitamin $\mathrm{D}_{3}$ supplementation on insulin sensitivity in apparently healthy, middle-aged, centrally obese men. Diabet Med 26, 19-27.

84. Borissova AM, Tankova T, Kirilov G, et al. (2003) The effect of vitamin $\mathrm{D}_{3}$ on insulin secretion and peripheral insulin sensitivity in type 2 diabetic patients. Int J Clin Pract 57, $258-261$.

85. von Hurst PR, Stonehouse W \& Coad J (2010) Vitamin D supplementation reduces insulin resistance in South Asian women living in New Zealand who are insulin resistant and vitamin D deficient - a randomised, placebocontrolled trial. Br J Nutr 103, 549-555.

86. Jorde R \& Figenschau Y (2009) Supplementation with cholecalciferol does not improve glycaemic control in diabetic subjects with normal serum 25-hydroxyvitamin D levels. Eur J Nutr 48, 349-354.

87. Pittas AG, Harris SS, Stark PC, et al. (2007) The effects of calcium and vitamin D supplementation on blood glucose and markers of inflammation in nondiabetic adults. Dia betes Care 30, 980-986.

88. Dawson-Hughes B, Harris SS, Krall EA, et al. (1997) Effect of calcium and vitamin D supplementation on bone density in men and women 65 years of age or older. $N$ Engl J Med 337, 670-676.

89. Jorde R, Sneve M, Torjesen P, et al. (2010) No improvement in cardiovascular risk factors in overweight and obese subjects after supplementation with vitamin $\mathrm{D}_{3}$ for 1 year. $J$ Intern Med 267, 462-472.

90. de Boer IH, Tinker LF, Connelly S, et al. (2008) Calcium plus vitamin D supplementation and the risk of incident diabetes in the Women's Health Initiative. Diabetes Care 31, $701-707$.

91. World Health Organization (2006) Obesity and Overweight. Fact sheet no. 311. http://www.who.int/ mediacentre/factsheets/fs311/en/index.html (accessed November 2008).

92. Flegal KM, Carroll MD, Ogden CL, et al. (2002) Prevalence and trends in obesity among US adults, 1999-2000. JAMA 288, 1723-1727.

93. McCarthy SN, Harrington KE, Kiely M, et al. (2001) Analyses of the anthropometric data from the North/South Ireland Food Consumption Survey. Public Health Nutr 4, 1099-1106

94. Lee P \& Cunningham K (1990) The Irish National Nutrition Survey. Dublin: Irish Nutrition and Dietetic Institute.

95. Pérez-López F (2009) Vitamin D metabolism and cardiovascular risk factors in postmenopausal women. Maturitas $\mathbf{6 2}$ 248-262.

96. Jorde R, Sneve M, Emaus N, et al. (2010) Cross-sectional and longitudinal relation between serum 25-hydroxyvitamin D and body mass index: the Tromso study. Eur $J$ Nutr 49, 401-407.

97. Compston JE, Vedi S, Ledger JE, et al. (1981) Vitamin D status and bone histomorphometry in gross obesity. Am J Clin Nutr 34, 2359-2363.

98. Harris SS \& Dawson-Hughes B (2007) Reduced sun exposure does not explain the inverse association of 25hydroxyvitamin D with percent body fat in older adults. $J$ Clin Endocrinol Metab 92, 3155-3157.

99. Bell NH, Epstein S, Greene A, et al. (1985) Evidence for alteration of the vitamin D-endocrine system in obese subjects. J Clin Invest 76, 370-373.

100. Shi H, Norman AW, Okamura WH, et al. (2001) 1 $\alpha, 25$-Dihydroxyvitamin $\mathrm{D}_{3}$ modulates human adipocyte metabolism via nongenomic action. FASEB J 15, 2751-2753. 
101. Zemel MB, Shi H, Greer B, et al. (2000) Regulation of adiposity by dietary calcium. FASEB J 14, 1132-1138.

102. Parikh SJ, Edelman M, Uwaifo GI, et al. (2004) The relationship between obesity and serum 1,25-dihydroxy vitamin D concentrations in healthy adults. J Clin Endocrinol Metab 89, 1196-1199.

103. Konradsen S, Ag H, Lindberg F, et al. (2008) Serum 1,25dihydroxy vitamin $\mathrm{D}$ is inversely associated with body mass index. Eur J Nutr 47, 87-91.

104. Wortsman J, Matsuoka LY, Chen TC, et al. (2000) Decreased bioavailability of vitamin D in obesity. Am J Clin Nutr $\mathbf{7 2}$ 690-693.

105. Arunabh S, Pollack S, Yeh J, et al. (2003) Body fat content and 25-hydroxyvitamin D levels in healthy women. $J$ Clin Endocrinol Metab 88, 157-161.

106. Freedman BI, Wagenknecht LE, Hairston KG, et al. (2010) Vitamin D, adiposity, and calcified atherosclerotic plaque in African-Americans. J Clin Endocrinol Metab 95, 1076-1083.

107. Sneve M, Figenschau Y \& Jorde R (2008) Supplementation with cholecalciferol does not result in weight reduction in overweight and obese subjects. Eur J Endocrinol 159, 675-684.

108. Caan B, Neuhouser M, Aragaki A, et al. (2007) Calcium plus vitamin D supplementation and the risk of postmenopausal weight gain. Arch Intern Med 167, 893-902.

109. Major GC, Alarie F, Dore J, et al. (2007) Supplementation with calcium + vitamin $\mathrm{D}$ enhances the beneficial effect of weight loss on plasma lipid and lipoprotein concentrations. Am J Clin Nutr 85, 54-59.

110. Major GC, Alarie FP, Dore J, et al. (2009) Calcium plus vitamin D supplementation and fat mass loss in female very low-calcium consumers: potential link with a calciumspecific appetite control. Br J Nutr 101, 659-663.

111. Zittermann A, Frisch S, Berthold HK, et al. (2009) Vitamin D supplementation enhances the beneficial effects of weight loss on cardiovascular disease risk markers. Am J Clin Nutr 89, 1321-1327.

112. Chobanian AV, Bakris GL, Black HR, et al. (2003) The Seventh Report of the Joint National Committee on Prevention, Detection, Evaluation, and Treatment of High Blood Pressure: the JNC 7 report. JAMA 289, 2560-2572.

113. Wang Y \& Wang QJ (2004) The prevalence of prehypertension and hypertension among US adults according to the new Joint National Committee guidelines: new challenges of the old problem. Arch Intern Med 164, 2126-2134.

114. Morgan K, McGee H, Watson D, et al (2008) SLÁN 2007, Survey of Lifestyle, Attitudes \& Nutrition in Ireland. Main Report. Dublin: Department of Health and Children.

115. Pilz S, Tomaschitz A, Ritz E, et al. (2009) Vitamin D status and arterial hypertension: a systematic review. Nat Rev Cardiol 6, 621-630.

116. Ballermann BJ \& Marsden PA (1991) Endothelium-derived vasoactive mediators and renal glomerular function. Clin Invest Med 14, 508-517.

117. Resnick LM, Muller FB \& Laragh JH (1986) Calcium-regulating hormones in essential hypertension. Relation to plasma renin activity and sodium metabolism. Ann Intern Med 105, 649-654.

118. Li YC, Kong J, Wei M, et al. (2002) 1,25-Dihydroxyvitamin $\mathrm{D}_{3}$ is a negative endocrine regulator of the renin-angiotensin system. J Clin Invest 110, 229-238.

119. Xiang W, Kong J, Chen S, et al. (2005) Cardiac hypertrophy in vitamin D receptor knockout mice: role of the systemic and cardiac renin-angiotensin systems. Am J Physiol Endocrinol Metab 288, E125-E132.

120. Kong J, Qiao G, Zhang Z, et al. (2008) Targeted vitamin D receptor expression in juxtaglomerular cells suppresses renin expression independent of parathyroid hormone and calcium. Kidney Int 74, 1577-1581.

121. Zhou C, Lu F, Cao K, et al. (2008) Calcium-independent and $1,25(\mathrm{OH})_{2} \mathrm{D}_{3}$-dependent regulation of the renin-angiotensin system in $1 \alpha$-hydroxylase knockout mice. Kidney Int 74, 170-179.

122. Yuan W, Pan W, Kong J, et al. (2007) 1,25-Dihydroxyvitamin $\mathrm{D}_{3}$ suppresses renin gene transcription by blocking the activity of the cyclic AMP response element in the renin gene promoter. J Biol Chem 282, 29821-29830.

123. Zemel M (2001) Calcium modulation of hypertension and obesity: mechanisms and implications. J Am Coll Nutr 20, 428-435.

124. Perkovic V, Hewitson TD, Kelynack KJ, et al. (2003) Parathyroid hormone has a prosclerotic effect on vascular smooth muscle cells. Kidney Blood Press Res 26, 27-33.

125. Rostand SG (1997) Ultraviolet light may contribute to geographic and racial blood pressure differences. Hypertension 30, 150-156.

126. Krause R, Buhring M, Hopfenmuller W, et al. (1998) Ultraviolet B and blood pressure. Lancet 352, 709-710.

127. Sowers MR, Wallace RB \& Lemke JH (1985) The association of intakes of vitamin D and calcium with blood pressure among women. Am J Clin Nutr 42, 135-142.

128. Jorde R \& Bonaa KH (2000) Calcium from dairy products, vitamin D intake, and blood pressure: the Tromso Study. Am J Clin Nutr 71, 1530-1535.

129. Forman JP, Bischoff-Ferrari HA, Willett WC, et al. (2005) Vitamin D intake and risk of incident hypertension: results from three large prospective cohort studies. Hypertension 46, 676-682.

130. Wang L, Manson JE, Buring JE, et al. (2008) Dietary intake of dairy products, calcium, and vitamin $\mathrm{D}$ and the risk of hypertension in middle-aged and older women. Hypertension 51, 1073-1079.

131. Pasco JA, Henry MJ, Nicholson GC, et al. (2009) Behavioural and physical characteristics associated with vitamin D status in women. Bone 44, 1085-1091.

132. Snijder MB, Lips P, Seidell JC, et al. (2007) Vitamin D status and parathyroid hormone levels in relation to blood pressure: a population-based study in older men and women. $J$ Intern Med 261, 558-565.

133. Jorde R, Figenschau Y, Emaus N, et al. (2010) Serum 25hydroxyvitamin D levels are strongly related to systolic blood pressure but do not predict future hypertension. Hypertension 55, 792-798.

134. Scragg R, Sowers M \& Bell C (2007) Serum 25-hydroxyvitamin D, ethnicity, and blood pressure in the Third National Health and Nutrition Examination Survey. Am J Hypertens 20, 713-719.

135. Judd SE, Nanes MS, Ziegler TR, et al. (2008) Optimal vitamin D status attenuates the age-associated increase in systolic blood pressure in white Americans: results from the third National Health and Nutrition Examination Survey. Am J Clin Nutr 87, 136-141.

136. Martins D, Wolf M, Pan D, et al. (2007) Prevalence of cardiovascular risk factors and the serum levels of 25-hydroxyvitamin D in the United States: data from the Third National Health and Nutrition Examination Survey. Arch Intern Med 167, 1159-1165.

137. Forman JP, Giovannucci E, Holmes MD, et al. (2007) Plasma 25-hydroxyvitamin D levels and risk of incident hypertension. Hypertension 49, 1063-1069.

138. Forman JP, Curhan GC \& Taylor EN (2008) Plasma 25-hydroxyvitamin D levels and risk of incident hypertension among young women. Hypertension $\mathbf{5 2}$, $828-832$. 
139. Scragg R, Khaw KT \& Murphy S (1995) Effect of winter oral vitamin $\mathrm{D}_{3}$ supplementation on cardiovascular risk factors in elderly adults. Eur J Clin Nutr 49, 640-646.

140. Orwoll ES \& Oviatt S (1990) Relationship of mineral metabolism and long-term calcium and cholecalciferol supplementation to blood pressure in normotensive men. Am J Clin Nutr 52, 717-721.

141. Margolis KL, Ray RM, Van Horn L, et al. (2008) Effect of calcium and vitamin D supplementation on blood pressure: the Women's Health Initiative Randomized Trial. Hypertension 52, 847-855.

142. Pfeifer M, Begerow B, Minne HW, et al. (2001) Effects of a short-term vitamin $\mathrm{D}_{3}$ and calcium supplementation on blood pressure and parathyroid hormone levels in elderly women. J Clin Endocrinol Metab 86, 1633-1637.

143. Cox RA \& Garcia-Palmieri MR (1990) Cholesterol, triglycerides, and associated lipoproteins. In Clinical Methods: The History, Physical and Laboratory Examinations, 3rd ed., Chapter 31, pp. 153-160 [HK Walker, WD Hall and JW Hurst, editors]. Stoneham, MA: Butterworth Publishers.

144. Tziomalos K, Athyros VG, Wierzbicki AS, et al. (2009) Lipoprotein a: where are we now? Curr Opin Cardiol 24, 351-357.

145. Ballantyne C, Arroll B \& Shepherd J (2005) Lipids and CVD management: towards a global consensus. Eur Heart J 26, 2224-2231.

146. Kendrick J, Targher G, Smits G, et al. (2009) 25-Hydroxyvitamin D deficiency is independently associated with cardiovascular disease in the Third National Health and Nutrition Examination Survey. Atherosclerosis 205, 255-260.

147. Bostom AG, Cupples LA, Jenner JL, et al. (1996) Elevated plasma lipoprotein(a) and coronary heart disease in men aged 55 years and younger. A prospective study. JAMA 276, 544-548.

148. Hopkins PN, Hunt SC, Schreiner PJ, et al. (1998) Lipoprotein(a) interactions with lipid and non-lipid risk factors in patients with early onset coronary artery disease: results from the NHLBI Family Heart Study. Atherosclerosis 141, 333-345.

149. Barger-Lux MJ, Heaney RP, Lanspa SJ, et al. (1995) An investigation of sources of variation in calcium absorption efficiency. J Clin Endocrinol Metab 80, 406-411.

150. Denke MA, Fox MM \& Schulte MC (1993) Short-term dietary calcium fortification increases fecal saturated fat content and reduces serum lipids in men. J Nutr 123, 1047-1053.

151. Reid IR (2004) Effects of calcium supplementation on circulating lipids: potential pharmacoeconomic implications. Drugs Aging 21, 7-17.

152. Vaskonen T, Mervaala E, Sumuvuori V, et al. (2002) Effects of calcium and plant sterols on serum lipids in obese Zucker rats on a low-fat diet. Br J Nutr 87, 239-245.

153. Cho HJ, Kang HC, Choi SA, et al. (2005) The possible role of $\mathrm{Ca}^{2+}$ on the activation of microsomal triglyceride transfer protein in rat hepatocytes. Biol Pharm Bull 28, 1418-1423.

154. Lacour B, Basile C, Drueke T, et al. (1982) Parathyroid function and lipid metabolism in the rat. Miner Electrolyte Metab 7, $157-165$.

155. Kelly GS (2005) Seasonal variations of selected cardiovascular risk factors. Altern Med Rev 10, 307-320.

156. Cigolini M, Iagulli MP, Miconi V, et al. (2006) Serum 25-hydroxyvitamin $\mathrm{D}_{3}$ concentrations and prevalence of cardiovascular disease among type 2 diabetic patients. Diabetes Care 29, 722-724.

157. Auwerx J, Bouillon R \& Kesteloot H (1992) Relation between 25-hydroxyvitamin $\mathrm{D}_{3}$, apolipoprotein A-I, and high density lipoprotein cholesterol. Arterioscler Thromb 12, 671-674.
158. Carbone LD, Rosenberg EW, Tolley EA, et al. (2008) 25-Hydroxyvitamin D, cholesterol, and ultraviolet irradiation. Metabolism 57, 741-748.

159. John WG, Noonan K, Mannan N, et al. (2005) Hypovitaminosis $\mathrm{D}$ is associated with reductions in serum apolipoprotein A-I but not with fasting lipids in British Bangladeshis. Am J Clin Nutr 82, 517-522.

160. Wang TJ, Pencina MJ, Booth SL, et al. (2008) Vitamin D deficiency and risk of cardiovascular disease. Circulation 117, 503-511.

161. Andersen R, Brot C, Mejborn H, et al. (2009) Vitamin D supplementation does not affect serum lipids and lipoproteins in Pakistani immigrants. Eur J Clin Nutr 63, 1150-1153.

162. Gannage-Yared MH, Azoury M, Mansour I, et al. (2003) Effects of a short-term calcium and vitamin D treatment on serum cytokines, bone markers, insulin and lipid concentrations in healthy post-menopausal women. J Endocrinol Invest 26, 748-753.

163. Rajpathak SN, Xue X, Wassertheil-Smoller S, et al. (2010) Effect of $5 \mathrm{y}$ of calcium plus vitamin D supplementation on change in circulating lipids: results from the Women's Health Initiative. Am J Clin Nutr 91, 894-899.

164. Daly RM \& Nowson CA (2009) Long-term effect of calcium-vitamin $\mathrm{D}_{3}$ fortified milk on blood pressure and serum lipid concentrations in healthy older men. Eur $J$ Clin Nutr 63, 993-1000.

165. Osmancevic A, Nilsen LT, Landin-Wilhelmsen K, et al. (2009) Effect of climate therapy at Gran Canaria on vitamin $\mathrm{D}$ production, blood glucose and lipids in patients with psoriasis. J Eur Acad Dermatol Venereol 23, 1133-1140.

166. Tuppurainen M, Heikkinen AM, Penttilä I, et al. (1995) Does vitamin $\mathrm{D}_{3}$ have negative effects on serum levels of lipids? A follow-up study with a sequential combination of estradiol valerate and cyproterone acetate and/or vitamin $\mathrm{D}_{3}$. Maturitas 22, 55-61.

167. Heikkinen AM, Tuppurainen MT, Niskanen L, et al. (1997) Long-term vitamin $\mathrm{D}_{3}$ supplementation may have adverse effects on serum lipids during postmenopausal hormone replacement therapy. Eur J Endocrinol 137, 495-502.

168. Wang JH, Keisala T, Solakivi T, et al. (2009) Serum cholesterol and expression of ApOAI, LXR $\beta$ and SREBP2 in vitamin D receptor knock-out mice. J Steroid Biochem Mol Biol 113, 222-226.

169. Wehmeier K, Beers A, Haas MJ, et al. (2005) Inhibition of apolipoprotein AI gene expression by 1, 25-dihydroxyvitamin $\mathrm{D}_{3}$. Biochim Biophys Acta 1737, 16-26.

170. Kowalska I, Straczkowski M, Nikolajuk A, et al. (2008) Insulin resistance, serum adiponectin, and proinflammatory markers in young subjects with the metabolic syndrome. Metabolism 57, 1539-1544.

171. Libby P (2002) Inflammation in atherosclerosis. Nature $\mathbf{4 2 0}$, 868-874.

172. Libby P, Ridker PM \& Maseri A (2002) Inflammation and atherosclerosis. Circulation 105, 1135-1143.

173. Stentz FB, Umpierrez GE, Cuervo R, et al. (2004) Proinflammatory cytokines, markers of cardiovascular risks, oxidative stress, and lipid peroxidation in patients with hyperglycemic crises. Diabetes 53, 2079-2086.

174. Moore K, de Waal Malefyt R, Coffman R, et al. (2001) Interleukin-10 and the interleukin-10 receptor. Annu Rev Immunol 19, 683-765.

175. Festa A, D’Agostino R Jr, Howard G, et al. (2000) Chronic subclinical inflammation as part of the insulin resistance syndrome: the Insulin Resistance Atherosclerosis Study (IRAS). Circulation 102, 42.

176. Ridker PM, Buring JE, Cook NR, et al. (2003) C-reactive protein, the metabolic syndrome, and risk of incident 
cardiovascular events: an 8-year follow-up of 14719 initially healthy American women. Circulation 107, 391-397.

177. Adams JS \& Hewison M (2008) Unexpected actions of vitamin D: new perspectives on the regulation of innate and adaptive immunity. Nat Clin Pract Endocrinol Metab 4, $80-90$.

178. Cantorna MT, Zhu Y, Froicu M, et al. (2004) Vitamin D status, 1,25-dihydroxyvitamin $\mathrm{D}_{3}$, and the immune system. Am J Clin Nutr 80, 1717S-1720S.

179. Herder C, Baumert J, Thorand B, et al. (2006) Chemokines as risk factors for type 2 diabetes: results from the MONICA/KORA Augsburg study, 1984-2002. Diabetologia 49, 921-929.

180. Deluca HF \& Cantorna MT (2001) Vitamin D: its role and uses in immunology. FASEB J 15, 2579-2585.

181. Mathieu C \& Adorini L (2002) The coming of age of 1,25dihydroxyvitamin $\mathrm{D}_{3}$ analogs as immunomodulatory agents. Trends Mol Med 8, 174-179.

182. Overbergh L, Decallonne B, Valckx D, et al. (2000) Identification and immune regulation of 25-hydroxyvitamin D1- $\alpha$-hydroxylase in murine macrophages. Clin Exp Immunol 120, 139 .

183. van Etten E \& Mathieu C (2005) Immunoregulation by 1, 25 dihydroxyvitamin $\mathrm{D}_{3}$ : basic concepts. J Steroid Biochem Mol Biol 97, 93-101.

184. van Etten E, Stoffels K, Gysemans C, et al. (2008) Regulation of vitamin D homeostasis: implications for the immune system. Nutr Rev 66, Suppl. 2, 125-134.

185. Zhu Y, Mahon BD, Froicu M, et al. (2005) Calcium and 1 $\alpha, 25$-dihydroxyvitamin $\mathrm{D}_{3}$ target the TNF- $\alpha$ pathway to suppress experimental inflammatory bowel disease. Eur $J$ Immunol 35, 217-224.

186. Talmor-Barkan Y, Rashid G, Weintal I, et al. (2009) Low extracellular $\mathrm{Ca}^{2+}$ : a mediator of endothelial inflammation. Nephrol Dial Transplant 24, 3306-3312.

187. Greenfield EM, Gornik SA, Horowitz MC, et al. (1993) Regulation of cytokine expression in osteoblasts by parathyroid hormone: rapid stimulation of interleukin- 6 and leukemia inhibitory factor mRNA. J Bone Miner Res 8, $1163-1171$.

188. Shea M, Booth S, Massaro J, et al. (2007) Vitamin K and vitamin D status: associations with inflammatory markers in the Framingham Offspring Study. Am J Epidemiol 167, 313-320.

189. Peterson C \& Heffernan M (2008) Serum tumor necrosis factor- $\alpha$ concentrations are negatively correlated with serum $25(\mathrm{OH})$ D concentrations in healthy women. $J$ Inflamm (Lond) 5, 10.

190. Van den Berghe G, Van Roosbroeck D, Vanhove P, et al. (2003) Bone turnover in prolonged critical illness: effect of vitamin D. J Clin Endocrinol Metab 88, 4623-4632.

191. Schleithoff SS, Zittermann A, Tenderich G, et al. (2006) Vitamin D supplementation improves cytokine profiles in patients with congestive heart failure: a double-blind, randomized, placebo-controlled trial. Am J Clin Nutr $\mathbf{8 3}$, 754-759.

192. Mahon B, Gordon S, Cruz J, et al. (2003) Cytokine profile in patients with multiple sclerosis following vitamin D supplementation. J Neuroimmunol 134, 128-132.

193. Jorde R, Sneve M, Torjesen PA, et al. (2010) No effect of supplementation with cholecalciferol on cytokines and markers of inflammation in overweight and obese subjects. Cytokine 50, 175-180.

194. Weinreich T, Wuthrich RP, Booy C, et al. (2001) Suppression of ICAM-1 expression in renal proximal tubular cells by 1,25-dihydroxyvitamin $\mathrm{D}_{3}$. Kidney Blood Press Res $\mathbf{2 4}$, 92-98.

195. Martinesi M, Bruni S, Stio M, et al. (2006) 1,25-Dihydroxyvitamin $\mathrm{D}_{3}$ inhibits tumor necrosis factor- $\alpha$-induced adhesion molecule expression in endothelial cells. Cell Biol Int 30, $365-375$.

196. Si-Feng C (1995) 1 $\alpha, 25$-Dihydroxyvitamin $\mathrm{D}_{3}$ decreased ICAM-1 and ELAM-1 expressions on pulmonary microvascular endothelial cells and neutrophil motivation. J Steroid Biochem Mol Biol 52, 67-70.

197. Kreft B, Brzoska S, Doehn C, et al. (1996) 1,25-Dihydroxycholecalciferol enhances the expression of MHC class II antigens and intercellular adhesion molecule- 1 by human renal tubular epithelial cells. J Urol 155, 1448-1453.

198. Kohler HP \& Grant PJ (2000) Plasminogen-activator inhibitor type 1 and coronary artery disease. N Engl J Med 342, $1792-1801$.

199. Thogersen A, Jansson J, Boman K, et al. (1998) High plasminogen activator inhibitor and tissue plasminogen activator levels in plasma precede a first acute myocardial infarction in both men and women: evidence for the fibrinolytic system as an independent primary risk factor. Circulation 98, 2241

200. Hamsten A, Wiman B, de Faire U, et al. (1985) Increased plasma levels of a rapid inhibitor of tissue plasminogen activator in young survivors of myocardial infarction. $N$ Engl J Med 313, 1557-1563.

201. Hamsten A, de Faire U, Walldius G, et al. (1987) Plasminogen activator inhibitor in plasma: risk factor for recurrent myocardial infarction. Lancet ii, 3-9.

202. Wu-Wong JR, Nakane M \& Ma J (2007) Vitamin D analogs modulate the expression of plasminogen activator inhibitor-1, thrombospondin- 1 and thrombomodulin in human aortic smooth muscle cells. J Vasc Res 44, 11-18.

203. Wu-Wong JR, Nakane M, Ma J, et al. (2006) Effects of vitamin $\mathrm{D}$ analogs on gene expression profiling in human coronary artery smooth muscle cells. Atherosclerosis 186, 20-28.

204. Vaughan DE, Lazos SA \& Tong K (1995) Angiotensin II regulates the expression of plasminogen activator inhibitor-1 in cultured endothelial cells. A potential link between the renin-angiotensin system and thrombosis. J Clin Invest 95, 995-1001.

205. Brown NJ, Agirbasli M \& Vaughan DE (1999) Comparative effect of angiotensin-converting enzyme inhibition and angiotensin II type 1 receptor antagonism on plasma fibrinolytic balance in humans. Hypertension 34, 285-290.

206. Jorde R, Sneve M, Torjesen P, et al. (2010) Parameters of the thrombogram are associated with serum 25-hydroxyvitamin D levels at baseline, but not affected during supplementation with vitamin D. Thromb Res 125, e210-e213.

207. Rahman A, Hershey S, Ahmed S, et al. (2007) Heart extracellular matrix gene expression profile in the vitamin D receptor knockout mice. J Steroid Biochem Mol Biol 103, 416-419.

208. Dollery C \& Libby P (2006) Atherosclerosis and proteinase activation. Cardiovasc Res 69, 625.

209. Dean D, Schwartz Z, Schmitz J, et al. (1996) Vitamin D regulation of metalloproteinase activity in matrix vesicles. Connect Tissue Res 35, 331-336.

210. Tai K, Need AG, Horowitz M, et al. (2008) Glucose tolerance and vitamin D: effects of treating vitamin D deficiency. Nutrition 24, 950-956.

211. Raghuramulu N, Raghunath M, Chandra S, et al. (1992) Vitamin D improves oral glucose tolerance and insulin secretion in human diabetes. J Clin Biochem Nutr 13, 45-51. 